\title{
Charitable Insolvency and Corporate Governance in Bankruptcy Reorganization
}

\begin{abstract}
by Reid K. Weisbord ${ }^{1}$
Poor corporate governance is pervasive in the charitable nonprofit sector and, in numerous cases, mismanagement and abuse have led to the financial distress or failure of charitable nonprofit firms. The rich literature on nonprofit law has considered the need for better corporate governance and enforcement of fiduciary duties, but the scholarship has failed to address the implications of financial distress and insolvency on corporate governance. This Article fills that void and argues that, when a charity encounters financial distress and approaches the point of insolvency, features of nonprofit and bankruptcy law tend to exacerbate rather than ameliorate the corporate governance problem. In particular, charitable insiders who breach their fiduciary duties are in a better position to entrench themselves and avoid termination than their for-profit counterparts. In the for-profit sector, three constraints tend to regulate corporate governance by helping oust fiduciaries responsible for financial distress: (1) bank monitoring of commercial loan covenants; (2) absolute priority and the transfer of ownership in bankruptcy; and (3) involuntary bankruptcy proceedings. In the nonprofit sector, however, those constraints are either less effective or do not apply. As a result, blameworthy charitable fiduciaries are better able to entrench themselves and, absent new leadership, financially distressed charities are less likely to achieve a full and sustainable financial recovery. This Article suggests that the law might better protect the public interest in charitable assets from waste and abuse by presumptively appointing bankruptcy examiners in all Chapter 11 reorganization proceedings involving substantial charitable assets. Once appointed, bankruptcy examiners would be tasked with identifying the cause of insolvency and individuals responsible for the charity's financial distress.
\end{abstract}

1. Vice Dean and Associate Professor of Law, Rutgers Law School-Newark. The author is especially grateful to the following scholars for offering helpful feedback on earlier drafts of this Article: Andrew Dawson, James Fishman, Pamela Foohey, Thomas Gallanis, Thomas Hazen, Melissa Jacoby, Jonathan Lipson, Chrystin Ondersma, and Stephen Urice. This article greatly benefited from the superlative research assistance of Nari Wang and Eileen McGlone. 


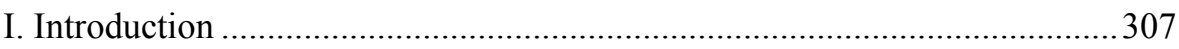

II. The Public Interest in Charitable Institutions and Assets .........................310

A. The Public Stake in Charitable Assets ................................................310

B. Bankruptcy Protection for Charitable Endowments Amplifies

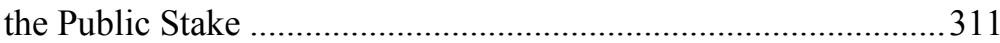

C. Successful Reorganization in Bankruptcy Serves the Public



III. The Quest for Charitable Accountability Outside of Bankruptcy..............316

IV. Fiduciary Accountability in Financially Distressed Charitable

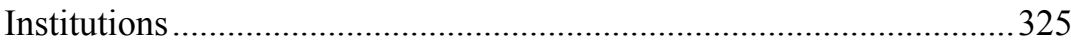



1. For-Profit Sector Loan Covenants .............................................325

2. Charitable Borrowing Patterns..................................................329

3. Donor Participation in Charitable Governance .......................... 333

B. Charitable Accountability in Bankruptcy Reorganization ................ 338

1. Unique Problems of Corporate Governance in Bankruptcy

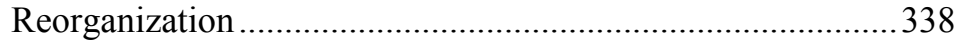

2. Bankruptcy Constraints on Corporate Governance:

Absolute Priority and the Transfer of Ownership and

Control.....

C. Charitable Exemption from Involuntary Proceedings.......................347

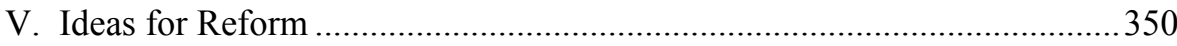

A. Bankruptcy as a Point of Governmental Intervention........................351

B. Presumptive Appointment of Bankruptcy Examiner ........................ 353

C. Repeal of charitable exemption from involuntary bankruptcy

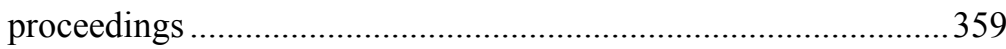




Charitable Insolvency and Corporate Governance in Bankruptcy Reorganization

\section{INTRODUCTION}

The charitable nonprofit form creates special problems of corporate governance by placing private actors in control of publicly subsidized charitable assets with little or no external oversight. Charitable officers and directors owe fiduciary duties to their charitable institutions, but state attorneys general or charitable beneficiaries rarely enforce those duties. Consequently, charitable assets are highly susceptible to mismanagement and abuse without detection or penalty imposed upon the breaching fiduciary. ${ }^{2}$ The problem of charitable accountability has been studied extensively, but legal scholars have yet to examine the corporate governance implications of insolvency and bankruptcy reorganization in the charitable nonprofit context. ${ }^{3}$ This void is significant because, when a charity encounters financial distress and approaches the point of insolvency, features of nonprofit and bankruptcy law usually exacerbate the corporate governance problem. As a result, charitable insiders who breach their fiduciary duties are more likely to remain in place than their for-profit counterparts. This harms the public interest in charitable assets by exposing the charity to further mismanagement and abuse. ${ }^{4}$

The financial distress of charitable nonprofit organizations implicates the public interest because charities share a symbiotic relationship with the public

2. Most charities "operate largely without supervision by any state official and with minimal oversight by the federal government, oversight, moreover, that is generally limited to assuring that they meet the conditions for exemption from federal taxes. Governments require no accountings of the methods by which nonprofit organizations pursue their missions nor make any attempt to assure that charitable assets are used effectively or efficiently." MARION FREMONT-SMITH, GOVERNING NONPROFIT ORgANIZATIONS 1-2 (Harvard University Press 2004); see also Part II, infra.

3. No legal scholarship has systemically addressed the corporate governance implications of charitable insolvency and the public interest in protecting charitable assets in bankruptcy. Indeed, the legal scholarship on charitable nonprofit bankruptcy more generally is scarce. As discussed below, the most important contributions in the area of charitable nonprofit bankruptcy are Evelyn Brody, The Charity in Bankruptcy and Ghosts of Donors Past, Present, and Future, 29 SETON Hall LEGIS. J. 471 (2005); Amelia Rawls, Applying the Absolute Priority Rule to Nonprofit Enterprises in Bankruptcy, 118 YALE L.J. 1231, 1243 (2009); and Pamela Foohey, Chapter 11 Reorganization and the Fair and Equitable Standard: How the Absolute Priority Rule Applies to All Nonprofit Entities, ST. JOHN's L. REV. (forthcoming). Other scholarship has addressed the bankruptcy of charitable nonprofit organizations in discrete contexts, such as church insolvencies following the sexual abuse scandal and nonprofit hospital systems affected by factors largely confined to the health care industry. The Seton Hall Legislation Journal hosted a symposium on "Bankruptcy in the Religious Non-Profit Context" and published resulting articles on the religious, constitutional, and sovereignty implications of church insolvency. SETON Hall Legis. J., Vol. 29, Issue 2 (2005). See also Jonathan C. Lipson, When Churches Fail: The Diocesan Debtor Dilemmas, 79 S. CAL. L. REV. 363 (2006). Regarding nonprofit hospital bankruptcies, see Harold L. Kaplan et al., The "Charitable Trust” Doctrine: Lessons and Aftermath of Banner Health, 23 AM. BANKR. INST. J. 28, 63 (2004) (opining that "in the insolvency context, application of the "charitable trust" theory could severely limit the ability of creditors, including tax-exempt bondholders, to recover against system assets that are encumbered by trust obligations--inasmuch as such assets could be deemed only available for designated charitable purposes and thereby even excluded from a bankruptcy estate").

4. This Article uses the term "charity" to refer to charitable nonprofit organizations with tax-exempt status under 26 U.S.C. $\S 501(\mathrm{c})(3)$. 
fisc - the charitable sector confers enormous public benefits on society and, in return, the public provides the charitable sector with substantial financial subsidies through the tax code and government grants. ${ }^{5}$ The significant investment of public resources in charitable assets vests the public with a financial stake in the efficient operation and sustained viability of all charities. ${ }^{6}$ Insolvency of a charitable nonprofit organization jeopardizes the public interest because it exposes subsidized charitable assets to the possibility of liquidation, which tends to undervalue the debtor's assets and, upon sale, typically terminates the charitable activity. Of course, the public interest is advanced when charities avoid financial distress and insolvency altogether; but for charities that do become insolvent, the public is served when otherwise viable charities avoid liquidation through financial rehabilitation. Chapter 11 of the Bankruptcy Code, which provides for business reorganization, can be used effectively to preserve the charity as a going concern, mitigate creditor losses, avoid the costly fire sale of charitable assets, and permit continuation of the charitable mission. ${ }^{7}$

Prospects for successful reorganization, however, are undermined when blameworthy incumbent fiduciaries - that is, charitable insiders who engage in negligent, self-dealing, or otherwise harmful conduct that causes a charity's financial distress - remain in place after the charity emerges from bankruptcy. Although bad leadership does not always cause insolvency, charitable mismanagement and abuse are major problems in the nonprofit sector. ${ }^{8}$ Outside the bankruptcy context, scholars have repeatedly criticized loose state and federal regulation for creating an environment wherein charitable fiduciaries can engage in negligence and disloyal conduct without detection or legal consequence. ${ }^{9}$ The same criticism should apply with even greater force when a charity becomes insolvent because marketplace systems and bankruptcy rules designed to constrain corporate fiduciaries in the for-profit context fail or do not apply in the charitable nonprofit context.

Blameworthy charitable fiduciaries can exploit three weaknesses in particular: (1) bank monitoring and intervention, which play significant nonbankruptcy roles in constraining corporate governance in the for-profit sector, are absent or less common in the charitable nonprofit sector; (2) bankruptcy reorganization, which facilitates a transfer of ownership and control in the forprofit sector, does not generally lead to new ownership of a reorganized charity; and (3) involuntary bankruptcy proceedings, which allow creditors to force insolvent for-profit debtors into bankruptcy, do not apply to charitable nonprofit debtors. ${ }^{10}$ Taken together, these factors increase the likelihood that blame-

5. See Part I.A, infra.

6. See Part II, infra.

7. See Part I, infra.

8. See Part II, infra.

9. Id.

10. See Part III, infra. 
Charitable Insolvency and Corporate Governance in Bankruptcy Reorganization

worthy charitable fiduciaries will remain in place despite their role in causing the charity's financial distress. Thus, charitable fiduciaries are better able to entrench themselves and engage in self-serving opportunism than their for-profit counterparts. The charities they supervise suffer, as a result.

This Article contains some nascent proposals for bankruptcy reform designed to prevent self-serving entrenchment by blameworthy charitable incumbents and deter charitable fiduciaries from violating their legal obligations before a charity becomes insolvent. For example, Congress might consider amending the Bankruptcy Code to provide for greater representation of the public interest by expanding the role of bankruptcy examiners in charitable nonprofit reorganizations. The Bankruptcy Code currently provides for the appointment of bankruptcy examiners to investigate allegations of fraud, incompetence, and misconduct by the debtor's incumbent managers and directors. Rather than reserving such appointments for cases in which a party alleges misconduct, examiners could be presumptively appointed in large charitable nonprofit reorganizations. The bankruptcy examiner system, a well-tested and largely successful program in the for-profit context, could potentially serve as a complement or substitute for representation of the public interest by the state attorney general. In cases where the appointment of a bankruptcy examiner would impose costs that exceed the benefits, the statutory presumption would force incumbent charitable fiduciaries to demonstrate why an examiner appointment is unnecessary. The examiner's report would be publicly available and provide bankruptcy courts with sufficient information to determine whether the charity will need further financial reorganization if left under the care of breaching incumbent fiduciaries. Such a finding would constitute grounds for the bankruptcy court to deny confirmation of the charity's reorganization plan, ${ }^{11}$ thereby hastening the resignation or removal of blameworthy officers and directors.

Congress might also consider repealing the charitable exemption from involuntary proceedings. Although involuntary proceedings are relatively rare in the for-profit debtor context, repealing this provision might increase pressure on charitable incumbents to seek bankruptcy relief sooner rather than later by giving creditors greater leverage when a charity reaches the point of insolvency. This, in turn, may increase the likelihood of successful reorganization by allowing charities to avoid the substantial costs and risks associated with the postponement of bankruptcy relief.

The Article proceeds as follows. Part I articulates a public interest in charitable assets and insolvent charitable nonprofit organizations. Part II describes the lack of charitable accountability that exists outside bankruptcy and the mismanagement of charitable assets arising from the failure to enforce fiduci-

11. 11 U.S.C. $\S 1129(a)(11)$ 
ary duties applicable to charitable officers and directors. Part III explains how bankruptcy law and certain features inherent to the charitable nonprofit form exacerbate the accountability problem once a charity becomes insolvent or enters bankruptcy reorganization, thus permitting blameworthy incumbents to entrench themselves in the reorganized charity. Part IV contains some nascent ideas for policy reform.

\section{The PUBliC INTEREST IN CHARITABLE INSTITUTIONS AND ASSETS}

This Part articulates a public interest in charitable assets and insolvent charitable institutions. It will argue that: (a) substantial tax subsidies vest the public with a financial stake in the operation and viability of all nonprofit charities; (b) bankruptcy protections amplify the public stake in charitable assets by excluding restricted charitable endowments from distribution to creditors; and (c) the public interest is generally served when financially distressed charities reorganize successfully in bankruptcy rather than liquidate charitable assets.

\section{A. The Public Stake in Charitable Assets}

Charities are private entities that exist to confer benefits on the community as a whole rather than on private individuals. ${ }^{12}$ Because the charitable sector resides at the intersection of interests public and private, leading scholars have offered numerous explanations for why the law confers upon charities preferential treatment including tax-exempt status. ${ }^{13}$ Perhaps the most intuitive explanation for the public's support of the charitable sector is that society is collectively better off when the hungry are fed, young people are educated, arts are promoted, and the sick receive medical care. Charitable activity can take place without public funding, but to encourage widespread participation, the government provides significant financial support for philanthropy in the form of tax subsidies, government grants, and other benefits at both federal and state levels.

12. See Model Nonprofit Corporation Act $\S \S 1.40(5)$ ("'Charitable corporation' means a domestic nonprofit corporation that is operated primarily or exclusively for one or more charitable purposes."; (6) ("'Charitable purpose' means a purpose that: (i) would make a corporation operated exclusively for that purpose eligible to be exempt from taxation under Section 501(c)(3) or (4) of the Internal Revenue Code, or (ii) is considered charitable under law other than this [act] or the Internal Revenue Code."); 26 U.S.C. § 501(c)(3) "Corporations, and any community chest, fund, or foundation, organized and operated exclusively for religious, charitable, scientific, testing for public safety, literary, or educational purposes, or to foster national or international amateur sports competition (but only if no part of its activities involve the provision of athletic facilities or equipment), or for the prevention of cruelty to children or animals, no part of the net earnings of which inures to the benefit of any private shareholder or individual, no substantial part of the activities of which is carrying on propaganda, or otherwise attempting, to influence legislation (except as otherwise provided in subsection (h)), and which does not participate in, or intervene in (including the publishing or distributing of statements), any political campaign on behalf of (or in opposition to) any candidate for public office.").

13. For a general theory of the role of charitable nonprofit organizations, see Henry B. Hansmann, The Role of Nonprofit Enterprise, 89 YALE L. J. 835 (1980) and the many citations thereto. 
Charitable Insolvency and Corporate Governance in Bankruptcy Reorganization

At the federal level, charitable assets ${ }^{14}$ are publicly subsidized in two ways through the Internal Revenue Code. First, when assets are given to charity, the tax code provides the donor with an income, gift, and estate tax deduction for the fair market value of the gift. ${ }^{15}$ Second, assets held by a tax-exempt organization are subsidized because income generated by the charity is exempt from the income tax (so long as the charity's net earnings relate to its charitable purpose).${ }^{16}$ Foregone tax revenue, often described as tax expenditures, yields substantial subsidies for the charitable sector; ${ }^{17}$ the federal income tax deduction for charitable gifts alone will account for $\$ 230$ billion in foregone tax revenue from 2010 to $2014 .{ }^{18}$ By one account, the federal government is the "largest single source of direct and indirect revenue for nonprofits." 19 Thus, the public has a tangible, financial, and investment-backed interest to ensure that charitable assets are put to proper use..$^{20}$

\section{B. Bankruptcy Protection for Charitable Endowments Amplifies the Public Stake}

Bankruptcy law, which generally applies to charities, ${ }^{21}$ tends to amplify the public interest in charitable assets by insulating restricted charitable endowments from distribution to unpaid creditors. Charitable endowments, products of state law, permit donors to restrict the donee's ability to spend the principal of a charitable gift on a current basis. In its classic form, an endowment grants the charitable donee a present right to income from the endowment but forbids invasion of principal. State law permits donors to impose restrictions of this sort by either: (1) creating a charitable trust with terms governing when, wheth-

14. The term "charitable asset" is defined by the Model Protection of Charitable Assets Act as "property that is given, received, or held for a charitable purpose." Model Protection of Charitable Assets Act $\S 2$, available at http://www.uniformlaws.org/shared/docs/protection_of_charitable_assets/mpocaa final_2011.pdf. The Act defines "charitable purpose" as "the relief of poverty, the advancement of education or religion, the promotion of health, the promotion of a governmental purpose, or any other purpose the achievement of which is beneficial to the community."

15. 26 U.S.C. $\S 170$ (income tax deduction); 26 U.S.C. $\S 2055$ (estate tax charitable deduction); 26 U.S.C. $\S 2522$ (gift tax charitable deduction).

16. 26 U.S.C. $\$ 501(\mathrm{c})(3)$.

17. Cf., Regan v. Taxation with Representation, 461 U.S. 540, 544 (1983) ("Both tax exemptions and tax deductibility are a form of subsidy that is administered through the tax system. A tax exemption has much the same effect as a cash grant to the organization of the amount of tax it would have to pay on its income. Deductible contributions are similar to cash grants of the amount of a portion of the individual's contributions.").

18. See http://www.cbo.gov/sites/default/files/cbofiles/attachments/10-18-charitableTestimony.pdf.

19. See, e.g., Lawrence Jacob Friedman \& Mark Douglas McGarvie, Charity, Philanthropy, and Civility in American History, 365 (Cambridge University Press, 2003).

20. See James J. Fishman, The Faithless Fiduciary and the Quest for Charitable Accountability: 1200-2005 at 283 (Carolina Academic Press 2007) (describing the federal interest in charitable accountability).

21. 11 U.S.C $\S 109$ (enumerating who may be a debtor, including, by implication, charitable nonprofit organizations). 
er, and in what amount the trustee may distribute income or principal to the charitable beneficiary, ${ }^{22}$ or (2) creating or contributing to an endowment fund that precludes the charitable donee from spending all or part of the gift on a current basis. ${ }^{23}$ Major charitable donors use this gift structure to provide longterm support rather than an infusion of cash for immediate use.

Although not specifically intended as a charitable protection, the Bankruptcy Code's treatment of restricted charitable endowments excludes certain restricted gifts from creditor collection by respecting property rights created outside of bankruptcy. ${ }^{24}$ When a debtor enters bankruptcy, all of the debtor's assets become part of a "bankruptcy estate," comprising of "all legal or equitable interests of the debtor in property." 25 The bankruptcy estate is legally distinct from the debtor, but "has no rights in the property broader than the rights of the debtor." ${ }^{26}$ If the debtor's pre-bankruptcy interest in property is restricted or impaired under non-bankruptcy law, then those restrictions generally apply once the debtor enters bankruptcy. ${ }^{27}$ Thus, when an insolvent charity files a bankruptcy petition, assets governed by such restrictions are excluded from the

22. A charitable trust establishes "a fiduciary relationship with respect to property arising as a result of a manifestation of an intention to create it, and subjecting the person by whom the property is held to equitable duties to deal with the property for a charitable purpose." Restatement (Second) of Trusts $\S 348$ (1959).

23. See Uniform Prudent Management of Institutional Funds Act § 2(2) (“"Endowment fund' means an institutional fund or part thereof that, under the terms of a gift instrument, is not wholly expendable by the institution on a current basis. The term does not include assets that an institution designates as an endowment fund for its own use.”). Forty-nine states have adopted the Uniform Prudent Management of Institutional Funds Act ("UPMIFA"), which "improves the protection of donor intent with respect to expenditures from endowments." Uniform Prudent Management of Institutional Funds Act, Prefatory Note, available at http://uniformlaws.org/Act.aspx?title=Prudent $\% 20$ Management $\% 20 \mathrm{of} \% 20$ Institutional\%20Fu nds\%20Act (listing the adopting states). Pennsylvania has not adopted UPMIFA, but provides similar protections for donor-imposed restrictions on expenditures from endowment funds. 15 Pa.C.S. § 5548.

23. In an endowment fund, the charitable donee may only withdraw amounts in accordance with the donor's written gift instrument, or if the donor did not specify a particular amount or formula, "an amount that is prudent, consistent with the purposes of the fund, relevant economic factors, and the donor's intent that the fund continue in perpetuity." Uniform Prudent Management of Institutional Funds Act, Prefatory Note.

24. For a thorough and thoughtful examination of the Bankruptcy Code's treatment of restricted charitable gifts, see Evelyn Brody, The Charity in Bankruptcy and Ghosts of Donors Past, Present, and Future, 29 SetON HALL LeGis. J. 471 (2005).

25. 11 U.S.C. $\S 541(a)$. "The scope of [§541(a)(1)] is broad. It includes all kinds of property, including tangible or intangible property, causes of action ..., and all other forms of property currently specified in section 70a of the Bankruptcy Act." H. R. Rep. No. 95-595, p. 367 (1977); see also S. Rep. No. 95-989, p. 82 (1978); United States v. Whiting Pools, 462 U.S. 198, 204-205 (1983) ("The House and Senate Reports on the Bankruptcy Code indicate that $§ 541$ (a)(1)'s scope is broad.").

26. Evelyn Brody, The Charity in Bankruptcy and Ghosts of Donors Past, Present, and Future, 29 SETON HALl LEGIS. J. 471, 475 (2005).

27. Butner v. United States, 440 U.S. 48, 55 (1979) ("Property interests are created and defined by state law. Unless some federal interest requires a different result, there is no reason why such interests should be analyzed differently simply because an interested party is involved in a bankruptcy proceeding."); 11 U.S.C. $\$ 541(\mathrm{c})(1)$ (directing inclusion in the estate of property subject to restrictions or conditions on transfer arising under nonbankruptcy law); 11 U.S.C. § 541(c)(2) ("A restriction on the transfer of a beneficial interest of the debtor in a trust that is enforceable under applicable nonbankruptcy law is enforceable in a case under this title."); Patterson v. Shumate, 504 U.S. 753, 759-60 (1992). 


\section{Charitable Insolvency and Corporate Governance in Bankruptcy Reorganization}

bankruptcy estate unless the charity enjoys a present right to consume them. ${ }^{28}$ This aspect of bankruptcy law, sometimes called the "charitable trust doctrine," allows charitable debtors to insulate restricted endowment funds from collection by creditors; for charities that maintain the bulk of their assets in a restricted endowment, the charitable trust doctrine is an especially potent form of asset protection..$^{29}$ For example, in its recent bankruptcy proceeding, the Philadelphia Orchestra protected its restricted endowment fund worth $\$ 116$ million over vigorous objection by unsecured creditors. ${ }^{30} \mathrm{~A}$ recent amendment to the Bankruptcy Code expanded this protection by prohibiting the transfer of property owned by a tax-exempt charity to a taxable entity unless permitted by state law. ${ }^{31}$ Charitable trusts enjoy similar protection because the Bankruptcy Code explicitly recognizes property interests held in trust. ${ }^{32}$

The charitable trust doctrine furthers the public interest by shielding subsidized charitable assets from creditor collection and retaining those assets for charitable use. However, the protection is incomplete because mere insulation of charitable assets from creditor collection is insufficient to protect against

28. See, e.g., Tort Claimants Comm. v. Roman Catholic Archbishop (In re Roman Catholic Archbishop), 345 B.R. 686 (Bankr. D. Or. 2006) (restricted church endowment containing \$36 million held in charitable trust and thus excluded from debtor's bankruptcy estate); In re St. Joseph's Hosp., 133 B.R. 453, 457 (Bankr. S.D. Ill. 1991). See generally, Evelyn Brody, The Charity in Bankruptcy and Ghosts of Donors Past, Present, and Future, 29 SeTON HALl LEGIS. J. 471 (2005).

29. See Harold L. Kaplan et al., The "Charitable Trust" Doctrine: Lessons and Aftermath of Banner Health, 23 AM. BANKR. INST. J. 28, 62-63 (2004).

30. Declaration of Richard B. Worley, 7-8, In re Philadelphia Orchestra Association, Doc. No. 12 , Case No. 11-13098 (E.D. Pa. Bank. Apr. 17, 2011).

31. The Bankruptcy Abuse Prevention and Consumer Protection Act of 2005 clarifies that property held by a charitable nonprofit debtor may be transferred to an entity without tax-exempt status under 26 U.S.C. \& 501(c)(3) only if state law would allow for such a transfer. See Bankruptcy Abuse Prevention and Consumer Protection Act of 2005, Pub. L. No. 108-9, 119 Stat. 23, § 1221; Bankruptcy Code section 541(f) now provides, "Notwithstanding any other provision of this title, property that is held by a debtor that is a corporation described in section 501(c)(3) of the Internal Revenue Code of 1986 and exempt from tax under section 501(a) of such Code may be transferred to an entity that is not such a corporation, but only under the same conditions as would apply if the debtor had not filed a case under this title.” 11 U.S.C. § 541(f). In other words, when a bankruptcy reorganization plan calls for transferring charitable assets to a for-profit entity, bankruptcy law respects state law restrictions that would preclude the transfer. The legislative history suggests the amendment was proposed in response to litigation in the Allegeheny Health System bankruptcy, a proposal criticized by members of the American Bankruptcy Conference for subjecting nonprofit bankruptcy proceedings to state law: Section 1127 [a prior version of 119 Stat. 23, § 1221] amends Section 363 and 1129(a) of the Code to require that transfers of property of a charitable corporation in bankruptcy must comply with state law. Section 541 of the Code is also amended to require that transfers of property of such corporations to other than a charitable corporation cannot be made except under the same conditions as would apply outside of bankruptcy. These amendments were sponsored solely as a result of one pending case of a number of hospitals in Pennsylvania and are inconsistent with bankruptcy policy. To require the Bankruptcy Court to abide by the diverse laws of 50 states when non-profit corporations seek bankruptcy is contrary to the establishment of a national uniform system. The law already recognizes that property rights in bankruptcy are initially defined by reference to state law, except when there is an overriding federal policy. Bankruptcy Reform Act of 1999 (Part I), Hearings before the Subcommittee on Commercial and Administrative Law of the House Judiciary Committee (Mar. 16, 1999) (statement of Leon S. Forman).

32. 11 U.S.C. $\S 541(\mathrm{c})(2)$ ("A restriction on the transfer of a beneficial interest of the debtor in a trust that is enforceable under applicable nonbankruptcy law is enforceable in a case under this title."). 
waste and abuse by the charity's own officers and directors. In cases involving negligence or wrongdoing by charitable fiduciaries, bankruptcy law must also ensure that, once preserved, restricted charitable endowments are not squandered by the same blameworthy individuals who led the charity into financial distress. Of course, as explained in greater detail below, the same holds true for unrestricted charitable assets as well: the law must protect non-endowment charitable assets from waste and abuse by nonprofit fiduciaries.

\section{Successful Reorganization in Bankruptcy Serves the Public Interest}

When a charity becomes insolvent, the public interest is jeopardized by the possibility that charitable assets will be liquidated, the worst possible outcome for a financially distressed charity. Liquidation not only terminates the charitable activity, but, according to some scholarship, may also tend to undervalue charitable assets as compared to their going concern value..$^{33}$ The public interest, therefore, is served when financially distressed (but economically viable) charities avoid liquidation by reorganizing under Chapter 11 of the Bankruptcy Code. ${ }^{34}$ Successful reorganization preserves economic resources and allows the debtor to emerge from bankruptcy intact as a going concern, thereby mitigating losses to all stakeholders including the public interest. ${ }^{35}$ By avoiding liquida-

33. Cf., Joseph Doherty and Lynn LoPucki, Bankruptcy Fire Sales, 106 Mich. L. REV. 1, 5, 44 (2007) ("Scholars and policymakers are in agreement that piecemeal sales are the least desirable alternative because they provide the lowest values"); Richard M. Hynes, Reorganization as Redemption, 6 VA. L. \& BUS. REV. 183, 189 (2011) ("insolvent firms may be unable to quickly raise money or sell assets at prices that reflect their assets' actual value due to transaction costs or a lack of information").

34. Reorganization is feasible so long as the debtor would be a viable economic enterprise but for its capital structure. Richard M. Hynes, Reorganization as Redemption, 6 VA. L. \& Bus. REV. 183, 185 (2011) ("The premise behind Chapter 11 is that some firms cannot meet their obligations (they are in financial distress) but still have sound business models (they are not in economic distress); these firms would be profitable if they could reorganize their capital structures."). As a rule of thumb, reorganization is a viable option when the present value of the debtor entity as a going concern exceeds the present value of liquidating its assets. See William D. Warren and Daniel J. Bussel, Bankruptcy 575 (Foundation Press $9^{\text {th }}$ Ed. 2012). Thus, to obtain confirmation of a reorganization plan, the proponent must show that "the plan is not likely to be followed by the liquidation [] or the need for further financial reorganization." 11 U.S.C. § 1129(a)(11).

35. "By permitting reorganization, Congress anticipated that the business would continue to provide jobs, to satisfy creditors' claims, and to produce a return for its owners. H. R. Rep. No. 95-595, at 220 (1977). Congress presumed that the assets of the debtor would be more valuable if used in a rehabilitated business than if "sold for scrap." United States v. Whiting Pools, 462 U.S. 198, 203 (1983); see also NLRB v. Bildisco \& Bildisco, 465 U.S. 513, 528 (1984) ("The fundamental purpose of reorganization is to prevent a debtor from going into liquidation, with an attendant loss of jobs and possible misuse of economic resources."); Bank of Am. Nat'l Trust \& Sav. Ass'n v. 203 N. Lasalle St. P'ship, 526 U.S. 434, 453 (1999) (The two primary goals of Chapter 11 reorganization are "preserving ongoing concerns and maximizing property available to satisfy creditors."); Elizabeth Warren, Bankruptcy Policymaking in an Imperfect World, 92 MiCH. L. REV. 336, 343 (1993).

Nineteenth Century lawyers devised the equity receivership, Chapter 11's legal predecessor, to preserve the assets of insolvent railroads as going concerns because the debtors' assets (rails, ties, and narrow strips of land) were worth far more as functional transportation networks than as individual assets liquidated for cash. See e.g., Douglas G. Baird \& Robert K. Rasmussen, Control Rights, Priority Rights, and the Conceptual Foundations of Corporate Reorganizations, 87 VA. L. REV. 921, 926 (2001) ("These railroads were worth keeping intact as going concerns even though their liabilities exceeded their assets. Once a railroad is built, much of the cost is sunk and there are no alternative uses for the 


\section{Charitable Insolvency and Corporate Governance in Bankruptcy Reorganization}

tion, creditors stand a chance of being repaid in the long run, employees of the debtor keep their jobs, and, most importantly from the public's perspective, subsidized charitable assets remain in charitable hands..$^{36}$ Empirical research on financially distressed for-profit businesses shows that bankruptcy reorganization is an effective way to preserve enterprise value as compared to liquidation or a fire sale of assets (although this has been the subject of a lengthy scholarly debate).$^{37}$ The same should hold true for charities.

Successful charitable reorganization can also protect important social interests that extend beyond the public's financial investment in charitable assets. For example, charities dedicated to the arts are often custodians of intangible assets that enrich society by providing cultural, civic, and social benefits that inure to the public as a whole but cannot be sold in a liquidation market. ${ }^{38}$ Consider, again, the Philadelphia Orchestra's recent bankruptcy. After more than a century of international prominence in symphonic performance and musical recording, the Philadelphia Orchestra was for the sole custodian of a unique style of musical performance known as the "Philadelphia Sound." ${ }^{39}$ Without a suc-

assets (the long, narrow strips of real property, the rails, the bridges, and the ties). It might make sense to sell off parts to or acquire lines from others, but the basic shape of the firm would remain unchanged. Piecemeal liquidation of the disparate assets in which creditors held security interests would generate meager returns and was not a sensible option.").

36. H.R. Rep. No. 95-595, at 220 (1977) ("The purpose of a business reorganization case, unlike a liquidation case, is to restructure a business's financings so that it may continue to operate, provide its employees with jobs, pay it creditors, and produce a return for its stockholders . . It is more economically efficient to reorganize than to liquidate, because it preserves jobs and assets." See also Andrew A. Wood, The Decline of Unsecured Creditor and Shareholder Recoveries in Large Public Company Bankruptcies, 85 AM. BANKR. L.J. 429, 429 (2001).

37. Joseph Dohert and Lynn LoPucki, Bankruptcy Fire Sales, 106 MiCH. L. REV. 1, 3 (2007) (“We found that companies sold for an average of $35 \%$ of book value but reorganized for an average freshstart value of $80 \%$ of book value and an average market capitalization value-based on postreorganization stock trading - of $91 \%$ of book value. Even controlling for the differences in the prefiling earnings of the two sets of companies, sale yielded less than half as much value as reorganization. These results suggest that creditors and shareholders can more than double their recoveries by reorganizing large public companies instead of selling them."). But see Michael Bradley and Michael Rosenzweig, The Untenable Case for Chapter 11, 101 YALE L.J. 1043 (1992) (arguing that the debtors' incumbent managers benefit more from bankruptcy reorganization than shareholders or bondholders); Douglas Baird, Revisiting Auctions in Chapter 11, 36 J.L. \& ECON. 633 (1993).

38. $C f$., Seaman, Bruce Alan, The Relationship Among Regional Economic Impact models: Contingent Valuation versus Economic Impact in the Case of Cultural Assets (http://ssrn.com/abstract= 975773) (noting the value of an arts organization to the surrounding community in terms of personal income, tax revenue (thereby increasing public safety, transportation, etc), jobs, and a "higher quality overall urban infrastructure"); Kaplan, Robert S., Conceptual Foundations of the Balanced Scorecard (March 1, 2010). Harvard Business School Accounting \& Management Unit Working Paper No. 10-074. Page 9, available at SSRN: http://ssrn.com/abstract=1562586 or http://dx.doi.org/10.2139/ssrn.1562586 ("Also, intangible assets seldom have value by themselves. Generally, they must be bundled with other intangible and tangible assets to create value. . The value does not reside in any individual intangible asset. It arises from creating the entire set of assets along with a strategy that links them together. The value-creation process is multiplicative, not additive.").

39. See, e.g., James R. Oestreich, 'Philadelphia Sound' Faces a Test of Time, N.Y. Times (Nov. 14, 2000) (attributing the Philadelphia Sound to "the acoustical qualities of the home auditorium," the ensemble's "own richness and length of articulation," the Orchestra's collection of fine Italian instruments (including a Stradivarius), a strong "generational connection from teacher to student within the orches- 
cessful reorganization in bankruptcy or sale as a going concern, the Philadelphia Orchestra would fold and cease performing as an ensemble. Liquidation would bring an end to a unique and cherished sound that took decades to cultivate and can be achieved only through live performance. The liquidation value of its intangible cultural assets would be worthless without a playing complement of musicians to continue the tradition of live symphonic performance. The cultural significance of the Philadelphia Orchestra as a performance ensemble is impossible to quantify (let alone sell), so society would suffer an irreplaceable loss. ${ }^{40}$

Successful reorganization, however, is inevitably undermined when reorganized charities are run by negligent, incompetent, or self-dealing fiduciaries. To protect the public interest, the bankruptcy reorganization process should vet incumbent fiduciaries and hold blameworthy individuals accountable for causing the charity's financial distress. In some cases, it may be appropriate for incumbent fiduciaries to remain in place following reorganization; retention of incumbents may be suitable, for instance, in cases where incumbent officers and directors properly discharged their obligations to the charity and the insolvency occurred for reasons beyond their control. In other cases, however, removal of some or all charitable fiduciaries may be required to protect the public interest from continued neglect, mismanagement, or misuse of charitable assets. As explained in the next section, charitable accountability is one of the major problems facing the nonprofit sector because federal and state oversight of charitable assets (outside of bankruptcy) is highly ineffective. Mismanagement and malfeasance by charitable fiduciaries is often not discovered until the charity encounters financial distress. Therefore, to protect the public interest, the bankruptcy reorganization process should serve as a point of governmental intervention for investigating the conduct of blameworthy charitable fiduciaries.

\section{The Quest FOR Charitable ACCOUNTABILITY OUtSIDE OF BANKRUPTCY}

This Part describes the problem of charitable accountability that generally pervades the nonprofit sector. Outside the bankruptcy context, charitable officers and directors are subject to little or no external oversight. Consequently, mismanagement and abuse of charitable assets are major problems, often going undetected and without remedy. This Part argues that poor corporate governance often leads to financial distress and the current legal regime inadequately holds charitable insiders accountable for breaching fiduciary duties.

tra, especially through the superb Curtis Institute in Philadelphia," and Maestro "Stokowski's introduction of free bowing into the strings.").

40. Another similar example would be the Martha Graham dance technique, which also requires live transmission to ensure continuation of the art. 


\section{Charitable Insolvency and Corporate Governance in Bankruptcy Reorganization}

In theory, the law protects the public interest in charitable assets through the nonprofit form, which interjects putatively trustworthy intermediaries (i.e., charitable officers and directors) between those who contribute and those who receive. ${ }^{41}$ The "nondistribution constraint," which prohibits the distribution of net earnings to those who control the charity, theoretically assures donors and other charitable patrons that the organization will devote all efforts to charitable activity rather than the pursuit of personal profit. ${ }^{42}$ But, as Professor Henry Hansmann warned long ago, "[i]f nonprofits are to fulfill their appropriate role, this constraint must be well defined and well policed." ${ }^{43}$ Policing the nondistribution constraint and ensuring that charitable managers discharge their responsibilities faithfully have proven to be difficult tasks. One particularly colorful illustration documents "the quest for charitable accountability" over an 800year period (1200-2005), proving that the regulation of charitable fiduciaries is quite literally "an age-old problem." 44

Legal scholarship has devoted a great amount of attention to the difficulty of enforcing fiduciary duties in the charitable nonprofit sector. ${ }^{45}$ While

41. The rich literature on theoretical justifications for the charitable nonprofit form was heavily influenced by Professor Henry B. Hansmann's seminal article, The Role of Nonprofit Enterprise, 89 YALE L. J. 835 (1980) (the nonprofit form facilitates the efficient provision of public goods by resolving the contract failure problem). For criticism of and response to this theory, see Ira Mark Ellman, Another Theory of Nonprofit Corporations, 80 MiCH. L. REV. 999 (1982); Rob Atkinson, Altruism in Nonprofit Organizations, 31 B.C.L. REV. 501 (1990).

42. Henry B. Hansmann, Reforming Nonprofit Corporation Law, 129 U. PA. L. REV. 497, 553 (1981); 26 U.S.C. § 501(c)(3).

43. Hansmann, supra note 42 , at 553.

44. JAMES J. Fishman, THE FAITHLESS FiduCIARY AND THE QUEST FOR CHARITABle ACCOUNTABiLity: 1200-2005, 307 (Carolina Academic Press 2007).

45. See generally Marion R. Fremont-Smith \& Andras Kosaras, Wrongdoings by Officers and Directors of Charities: A Survey of Press Reports 1995-2002, 42 EXEMPT ORG. TAX REV. 25 (2003); Ronald Chester, Improving Enforcement Mechanisms in the Charitable Sector: Can Increased Disclosure of Information Be Utilized Effectively?, 40 New EnG. L. Rev. 447 (2006); Evelyn Brody, Agents Without Principals: The Economic Convergence of the Nonprofit and For-Profit Organizational Forms, 40 N.Y. SCH. L. REV. 457 (1996); Ellen P. Aprill, What Critiques of Sarbanes-Oxley Can Teach About Regulation of Nonprofit Governance, 76 FORDHAM L. REV. 765 (2008); Dana Brakman Reiser, There Ought to Be a Law: The Disclosure Focus of Recent Legislative Proposals for Nonprofit Reform, 80 CHI.KENT L. REV. 559 (2005); Susan N. Gary, Regulating the Management of Charities: Trust Law, Corporate Law, and Tax Law, 21 U. HAw. L. REV. 593 (1999); Evelyn Brody, Charity Governance: What's Trust Law Got to Do with It?, 80 CHI-KeNT L. REV. 641 (2005); James J. Fishman, Improving Charitable Accountability, 62 MD. L. REv. 218 (2003). Congress has expressed deep concern over the conduct of charitable nonprofits in a regulatory environment of lax oversight and supervision. Senator Max Baucus, for example, observed:

But while many charities are focused on doing good works and preserving the public trust, there have been a number of high-profile examples of problems in this expanding sector: inflated salaries paid to trustees and charity executives, insider deals with insufficient transparency, charities engaging in abusive tax shelters, and charities serving as conduits to finance terrorist activities and operations. This proliferation of sloppy, unethical, and criminal behavior is unacceptable. It has led to a crisis in confidence. It has hurt fundraising by legitimate charities. And it overshadows the good work done by the majority of civic minded groups. Like the recent corporate scandals, these events make Americans second-guess their faith in bedrock institutions. 
state law imposes fiduciary duties of care and loyalty (and, in some states, obedience), ${ }^{46}$ those duties, in practice, provide nominal protection for charitable assets because they are seldom enforced. ${ }^{47}$ In the rare case where enforcement occurs and reaches the point of litigation, courts have abstained from imposing personal liability or removing blameworthy fiduciaries from office even upon finding a breach of fiduciary duty. ${ }^{48}$ The charitable nonprofit corporation permits indemnification of officers and directors from personal liability arising from a good faith breach of fiduciary duty. Thus, since most charities are charitable nonprofit corporations, there is rarely any threat of personal liability to compel the faithful exercise of care. ${ }^{49}$

The government is often the sole party with authority or ability to regulate the conduct of charitable fiduciaries. To this end, long-standing common law (now codified by statute in many states) vests state attorneys general with pow-

United States Senate Committee on Finance, Charity Oversight and Reform: Keeping Bad Things from Happening to Good Charities (June 22, 2004) (Statement of U.S. Senator Max Baucus), available at http://finance.senate.gov/imo/media/doc/062204mb1.pdf.

46. See, e.g., Model Nonprofit Corporation Act, 3d Ed. (2008) $\S \S 8.30$ (duty of care); 8.60, 8.70 (duty of loyalty); Manhattan Eye, Ear \& Throat Hospital v. Spitzer, 186 Misc.2d 126 (1999) (duty of obedience to the organization's charitable mission). See generally, DANIEL L. KURTZ, BOARD LIABILITY: A GUIDE FOR NONPROFIT DIRECTORS, 84-85 (Moyer Bell 1989).

47. See, e.g., James J. Fishman, The Faithless Fiduciary and the Quest for Charitable Accountability: 1200-2005 at 278 (Carolina Academic Press 2007) ("Despite a recent flurry of high-profile cases in a few states, regulation at the state level has been neither efficient nor effective. The lack of resources, the lack of will, and more pressing other responsibilities have made state regulation of charities more theoretical than real."). For a 50-state survey of fiduciary duties applicable to charitable officers and directors, see Marion Freemont-Smith, Governing Nonprofit Organizations, Table 3 (appendix) (Harvard University Press 2004).

48. See, e.g., Stern v. Lucy Webb Hayes National Training School for Deaconesses, 381 F. Supp. 1003 (1974) ("Removal of the defendant trustees from the Sibley Board would be unduly harsh, and this will not be ordered. These trustees are now completing long years of service and they will soon become less active in the day-to-day affairs of the Hospital because of age or illness."); The Principles of the Law of Nonprofit Organizations, currently in tentative draft form, takes the position that monetary liability should not be imposed on "a fiduciary who either made no decision (notably, in the oversight context) or made a decision that does not satisfy the business judgment rule." The Principles of the Law of Nonprofit Org. (Tentative Draft 1, April 2011) § $370 \mathrm{cmt}$. a. The Principles also state that removal should be reserved for the most egregious offenses:

Courts generally will remove only upon a finding of repeated or flagrant disregard of or failure to exercise the duty of care, or a material breach of the duty of loyalty. Removal of a member of the governing board who has acted in good faith is ordinarily not appropriate if the charity has or agrees to put in place those structures and procedures conducive to good governance, and if the governing-board member can be expected to adhere to the required fiduciary standards in the future. Removal might more readily be ordered in the case of gross mismanagement of a large, commercial enterprise such as a nonprofit hospital or university, or of a board member whose behavior is unreasonably uncooperative, if not hostile.

The Principles of the Law of Nonprofit Org. (Tentative Draft 1, April 2011) $\$ 360 \mathrm{cmt} \mathrm{c.}$

49. See, e.g., Model Nonprofit Corporation Act, 3d Ed. $\S 8.51$ (2008); Thomas Lee Hazen \& Lisa Love Hazen, Punctilios and Nonprofit Corporate Governance-A Comprehensive Look at Nonprofit Directors' Fiduciary Duties, 14 U. PA. J. Bus. L. 347, 412 (2012) ("Nonprofit directors in most states may take advantage of the limited immunity for volunteers. The rationale is that immunity will encourage volunteerism."). 
Charitable Insolvency and Corporate Governance in Bankruptcy Reorganization

er to represent the public interest in matters concerning charitable assets. ${ }^{50}$ In theory, the attorney general's oversight is superior to supervision by private parties because no single individual has a sufficient stake in charitable assets to warrant representing the public interest. ${ }^{51}$ In practice, however, state attorneys general rarely invoke their authority to investigate or remedy breaches of fiduciary duties by charitable officers and directors. ${ }^{52}$ For various reasons, state attorneys general do not pursue fiduciary enforcement with the same tenacity as they do when prosecuting other types of misconduct. ${ }^{53}$ Charitable enforcement activity is mostly limited to conduct involving fraudulent charitable solicitation. ${ }^{54}$

In the quest for accountability, scholars have searched for a neutral party other than the state attorney general to enforce fiduciary duties and represent the public interest in charitable assets, but a satisfactory solution has proved elusive. Donors recently acquired standing to enforce the terms of a restricted charitable gift in number of states, but the grant of standing is narrowly prescribed and generally precludes intervention in governance matters unrelated to the donor's gift. ${ }^{55} \mathrm{~A}$ broader grant of donor standing would be unlikely to solve the accountability problem because charitable donors tend to incur the cost of enforcement litigation to vindicate only their own interests, which are often more narrow and subjective than the public interest. ${ }^{56}$ The Internal Revenue Service, authorized by Congress to impose "intermediate sanctions" in cases of

50. See, e.g., Conn. Gen. Stat. Ann. § 3-125; Idaho Code Ann. § 67-1401; Mich. Comp. Laws Ann. § 14.251; Me. Rev. Stat. Tit. 5, § 194.

51. See, e.g., Pruner Estate, 136 A.2d 107, 109 (Pa. 1957); see also Lisa M. Bell \& Robert B. Bell, Supervision of Charitable Trusts in California, 32 HAST. L.J. 433, 434 (1980).

52. See, e.g., Lisa M. Bell \& Robert B. Bell, Supervision of Charitable Trusts in California, 32 HAST. L.J. 433, 435 (1980); Lloyd Hitoshi Mayer \& Brendan M. Wilson, Regulating Charities in the Twenty-First Century: An Institutional Choice Analysis, 85 CHI.-KENT L. REV. 479, 494 (2010). Professor Henry Hansmann's observation about attorney general enforcement in 1981 remains true today: Unfortunately, in most states there has been little effort to exercise even the substantial powers that the attorney general already has. Commonly, little or no staff in the attorney general's office is assigned to look after the affairs of nonprofits, and no effective system of financial reporting by nonprofits exists in any state. Moreover, among the few states that make some organized effort in this area, policing often is largely confined to charitable trusts. This sad state of affairs has, at various times, been prominently noted and loudly bemoaned, but with little effect.

Henry Hansmann, Reforming Nonprofit Corporation Law, 129 U. PA. L. REV. 497, 601 (1981)

53. Evelyn Brody, Whose Public? Parochialism and Paternalism in State Charity Law Enforcement, 79 Ind. L. J. 937,947 (2008).

54. See, e.g., id.; In 2011, the National Conference of Commissioners on Uniform State Laws adopted the Model Protection of Charitable Assets Act, which confirms and clarifies the duty of state attorneys general with regard to charitable assets. See Prefatory Note ("The Act adopts registration, reporting, and notice requirements that will enable the Attorney General to fulfill the responsibility of that office to represent the public interest by protecting charitable assets.")

55. Uniform Trust Code $\S 405$ (c) (granting settlor standing to enforce the terms of a charitable trust); Restatement (Third) of Trusts $\S 94 \mathrm{cmt}$. d(2) ("Neither the settlor nor the personal representative or successors in interest of the settlor can, as such, maintain a suit against the trustee to enjoin or redress a breach of trust or otherwise to enforce the trust, absent contrary legislation.").

56. See generally, Reid K. Weisbord \& Peter DeScioli, The Effects of Donor Standing on Philanthropy: Insights from the Psychology of Gift-Giving, 45 GonZ. L. REV. 225 (2010). 
nonprofit self-dealing and private inurement, infrequently investigates such conduct and lacks statutory authority to pursue enforcement in cases of pure mismanagement. ${ }^{57}$ Another approach proposed by scholars is the creation of new oversight agencies supervised by the state attorney general, Internal Revenue Service, or a quasi-public regulatory body, but such proposals have yet to be enacted. ${ }^{58}$ Federal law now requires most tax-exempt charities to disclose more information about their operation to the public, ${ }^{59}$ but heightened transpar-

57. 26 U.S.C. $\S 4958$ (imposing intermediate sanctions on self-dealing transactions); James J. Fishman, Improving Charitable Accountability, 62 MD. L. REV. 218, 265-67 (2003) (noting the infrequency of IRS scrutiny of charitable nonprofit organizations).

In one recent scandal, for example, founders of the tax-exempt Trinity Broadcasting Network were accused by their granddaughter of classic private inurement: "My job as finance director was to find ways to label extravagant personal spending as ministry expenses." Erik Eckholm, Family Battle Offers Glimpse Inside a Lavish TV Ministry, N.Y. Times (May 5, 2012 at A1). Notably, the alleged misconduct was not uncovered by the IRS despite the founders' lavish real estate purchases in California and Florida: "Mr. and Mrs. Crouch have his-and-her mansions one street apart in a gated community here, provided by the networking using viewer donations and tax-free earnings. But Mrs. Crouch, 74, rarely sleeps in the $\$ 5.6$ million house with tennis court and pool. She mostly lives in a large company house near Orlando, Fla., where she runs a side business, the Holy Land Experience theme park. Mr. Crouch, 78 has an adjacent home there too, but rarely visits. Its occupant is often a security guard who doubles as Mrs. Crouch's chauffeur." Id.

58. James J. Fishman, Improving Charitable Accountability, 62 MD. L. REV. 218, 272 (2003) (proposing a state-level citizen advisory commission); Terri Lynn Helge, Policing the Good Guys: Regulation of the Charitable Sector Through A Federal Charity Oversight Board, 19 CORNELL J. L. \& PuB. POL'Y 1, 68 (2009) (proposing a quasi-public regulatory body supervised by the IRS); See also Evelyn Brody, Institutional Dissonance in the Nonprofit Sector, 41 VILL. L. REV. 433, 477-87 (1996) (discussing proposals on ways to shrink the nonprofit sector, the creation of an agency to supervise charities, mandated disclosures, and the expansion of standing rights); Joshua B. Nix, The Things People Do When No One is Looking: an Argument for the Expansion of Standing in the Charitable Sector, $14 \mathrm{U}$. MiAMI BuS. L. REV. 147, 168-86 (2005) (describing disclosure and accountability reforms including public access to Form 990s, a Sarbannes-Oxley type legislation for nonprofits, intermediate sanctions, additional funds for the IRS and the Attorney General, and relaxing standing requirements for plaintiffs); Harvey J. Goldschmid, The Fiduciary Duties of Nonprofit Directors and Officers: Paradoxes, Problems, and Proposed Reforms, 23 IOWA J. CORP. L. 631, 650-53 (1998) (suggesting improved guidelines in the broad duty of loyalty, process specifications, and conduct specifications, increasing capacity of state regulators and the IRS, permitting donor, member, and beneficiary derivative actions); Carter G. Bishop, The Deontological Significance of Nonprofit Corporate Governance Standards: a Fiduciary Duty of Care Without a Remedy, 57 CATH. U. L. REV. 701 (2008) (discussing the adoption of SarbannesOxley reforms by nonprofit organization, a drafting project by the American Law Institute delineating a charitable board members' fiduciary duties, increasing the initial excise tax, extending the prohibition for self-dealing to public charities, whistleblower reforms); Kenneth L. Karst, The Efficiency of the Charitable Dollar: An Unfulfilled State Responsibility, 73 HARV. L. REv. 433, 476 (1960) (proposing the establishment of a state agency to supervise private charities and regulate their operation); Dana Brakman Reiser, There Ought to be a Law: The Disclosure Focus of Recent Legislative Proposals for Nonprofit Reform, 80 CHI.-KENT L. REV. 559 (2005) (discussing recent disclosure-based reforms in the nonprofit sector); Joseph Mead, Confidence in the Nonprofit Sector Through Sarbanes-Oxley-Style Reforms, 106 MICH. L. REV. 881 (2008) (critiquing various proposals of Sarbanes-Oxley type requirements on nonprofits); Henry B. Hansmann, Reforming Nonprofit Corporation Law, 129 U. PA. L. REV. 497 (1981) (suggesting more rigorous standards of enforcement including disclosure).

59. The Pension Protection Act of 2006 provides that charitable nonprofits must file IRS Form 990 or face revocation of tax-exempt status under 26 U.S.C. § 501(c). See James J. Fishman, Wrong Way Corrigan and Recent Developments in the Nonprofit Landscape: A Need for New Legal Approaches, 76 FORDHAM L. REV. 567, 588 (2007). In 2008, the IRS amended Form 990 requiring charitable nonprofits to disclose additional information about their operations. IRS, Implementation of Form 990 - Internal Revenue Bulletin (Oct. 27, 2008), available at http://www.irs.gov/irb/2008-43_IRB/ar07.html. Once filed, the Form 990 is available on the Internet through services such as Guidestar.org. 


\section{Charitable Insolvency and Corporate Governance in Bankruptcy Reorganization}

ency alone is insufficient to constrain agency costs without a party to act as enforcer. Thus, the current state of the law holds charitable officers and directors largely unaccountable for their actions and the organizations they serve suffer, as a result. ${ }^{60}$

Agency cost theory suggests that the problem of charitable accountability is inherent to the nonprofit form because it allows agents to control charitable assets without supervision by principals. ${ }^{61}$ Economists define agency costs as the loss of welfare caused by divergent interests between a principal and agent. ${ }^{62}$ When a principal hires an agent to perform a task, the agent's self-interest can (and often does) conflict with the principal's objectives, thereby shifting economic rents from the principal to the agent unless the principal incurs monitoring costs to constrain the agent's behavior. ${ }^{63}$ Principals can mitigate such costs by properly aligning the agent's interests, monitoring the agent's performance, or terminating the agent.

In the for-profit corporate form, agency costs exist but are restrained because principals (corporate shareholders) have the power to monitor and regulate agents (corporate officers and directors). ${ }^{64}$ Shareholders can exercise voting rights to align the interests of officers and directors (e.g., by linking compensa-

60. Professor Evelyn Brody explains: Finally, we reach what some observers lament as the core hypocrisy of the nonprofit governance legal regime: that the standard of care is precatory only, because few parties can complain about fiduciary wrongdoing, and, even when the attorney general or other person with standing does bring suit, courts will not impose meaningful sanctions. Evelyn Brody, The Board of Nonprofit Organizations: Puzzling Through the Gaps Between Law and Practice, 76 FORDHAM L. REV. 521, 561-63 (2007) (noting that private parties often lack standing to directors for breach of fiduciary duties, that when such suits do reach the merits, the business judgment rule shields decisions made in good faith, and when a violation is found, the sanctions are light or non-existent).

61. See, e.g., Geoffrey A. Manne, Agency Costs and the Oversight of Charitable Organizations, 1999 WIS. L. REV. 227 (1999).

62. Professors Jensen and Meckling's definition of agency costs are widely accepted in the literature: We define an agency relationship as a contract under which one or more persons (the principal(s)) engage another person (the agent) to perform some service on their behalf which involves delegating some decision making authority to the agent. If both parties to the relationship are utility maximizers, there is good reason to believe that the agent will not always act in the best interests of the principal. The principal can limit divergences from his interest by establishing appropriate incentives for the agent and by incurring monitoring costs designed to limit the aberrant activities of the agent. In addition in some situations it will pay the agent to expend resources (bonding costs) to guarantee that he will not take certain actions which would harm the principal or to ensure that the principal will be compensated if he does take such actions. However, it is generally impossible for the principal or the agent at zero cost to ensure that the agent will make optimal decisions from the principal's viewpoint. In most agency relationships the principal and the agent will incur positive monitoring and bonding costs (non-pecuniary as well as pecuniary), and in addition there will be some divergence between the agent's decisions and those decisions which would maximize the welfare of the principal. Michael C. Jensen \& William H. Meckling, Theory of the Firm: Managerial Behavior, Agency Costs and Ownership Structure, 3 J. FIN. ECON. 305, 308 (1976).

63. Id.

64. But see Margaret M. Blair \& Lynn A. Stout, Director Accountability and the Mediating Role of the Corporate Board, 79 WASH. U. L.Q. 403, 408 (2001) ("[T]he primary economic function of directors in public corporations may not be to act as shareholders' agents but, instead, to serve as 'mediating hierarchs' charged with balancing the sometimes competing interests of a variety of groups that participate in public corporations.") 
tion to the company's long-term financial performance) or vote out underperforming fiduciaries. Shareholders can monitor the agency by reviewing audited financial reports and keeping tabs on the company's stock performance. Shareholders can terminate the agency by selling the stock. Thus, the for-profit corporate model separates ownership from control but contains structural protections - corporate democracy and liquidity-for constraining agency costs inherent in the relationships among shareholders, managers, and directors. ${ }^{65}$

By contrast, agency costs are acutely present in the charitable nonprofit form because there is typically no principal empowered to monitor, fire, or control the agent. ${ }^{66} \mathrm{~A}$ defining characteristic of the charitable nonprofit form is the lack of proprietary ownership - i.e., there are no shareholders with a financial incentive to monitor or remove underperforming charitable fiduciaries. ${ }^{67}$ The principals - charitable beneficiaries and public at large - generally have no role in nonprofit governance matters and rarely have the information, organization, or funding necessary to bring suit for breach of fiduciary duty. ${ }^{68}$ Indeed, most charities are entirely governed by agents - charitable officers and directorswho are effectively permitted to regulate their own conduct and face few, if any, consequences for failing to do so properly. As Judge Richard Posner observes: "[A]s neither the trustees nor the staff have the kind of property right in the [charity's] assets or income that would give them a strong incentive to maximize value, the carrot is missing along with the stick." ${ }^{69}$

Agency costs in the charitable nonprofit setting manifest in various forms, some more harmful than others. In non-membership charities, ${ }^{70}$ the board of

65. See generally Adolph A. Berle, Jr. \& Gardiner C. Means, The Modern Corporation and Private Property (1932). But see Lucian Arye Bebchuk, The Case for Shareholder Access to the Ballot, 59 BUS. LAW. 43, 45-46 (2003) (arguing that, in practice, for-profit corporate boards tend to be self-perpetuating rather than selected by shareholders). Professor Bebchuck argues that current proxy solicitation contest rules are insufficient to provide shareholders access to director nominations because of the high cost of soliciting proxies and because shareholders do not capture all of the increase in value from a successful proxy solicitation contest. Bebchuk analyzed data on contested solicitations from 1996 to 2002 and concluded that possibility of directors being removed by shareholders because of poor management was so low as to be negligible. Past studies showed that excessive director "insulation" from the risk of removal harmed the corporation and shareholders because directors had insufficient incentives to act in the best interest of the shareholders.

66. See generally Evelyn Brody, Agents Without Principals: The Economic Convergence of the Nonprofit and For-Profit Organizational Forms, 40 N.Y.L. SCH. L. REV. 457 (1996).

67. See Geoffrey A. Manne, Agency Costs and the Oversight of Charitable Organizations, 1999 WIS. L. REV. 227, 227-28 (1999); 26 U.S.C. § 501(c)(3) (prohibiting private inurement from charitable nonprofits).

68. See, e.g., Kenneth L. Karst, The Efficiency of the Charitable Dollar: An Unfulfilled State Responsibility, 73 HarV. L. ReV. 433, 436-37 (1960); Terri Lynn Helge, Policing the Good Guys: Regulation of the Charitable Sector Through a Federal Charity Oversight Board, 19 CORNELL J. L. \& PUB. POL'Y 1, 16 (2009). Cf., Evelyn Brody, The Limits of Charity Fiduciary Law, 57 MD. L. REv. 1400, 1430-1431 (1998) ("Nor, except in rare cases, do beneficiaries have standing to sue charity trustees or directors, either directly or derivatively on behalf of the charity, because 'the human beings who are favorably affected by the execution of the trust are merely the media through whom the social advantages flow to the public."').

69. Richard A. Posner, ECONOMic ANALYSis OF LAW § 18.5, at 698 (8th ed. 2010).

70. Charitable nonprofit organizations have the option of creating a class of non-equity members en- 


\section{Charitable Insolvency and Corporate Governance in Bankruptcy Reorganization}

directors is a self-perpetuating body wherein new directors are selected by the incumbent board. ${ }^{71}$ This governance structure often leads to homogenous board composition and appointments driven by personal connections rather than evaluation of the candidate's bona fide qualifications. ${ }^{72}$ While the board of directors is primarily responsible for institutional governance, many charitable boards are composed of volunteer directors who generally follow the path of least resistance; directors are often willing to attend quarterly meetings but refuse to engage in time-consuming, meaningful organizational oversight. ${ }^{73}$ Nonprofit directors often view their appointments as salutary rather than supervisory, so they tend to ratify decisions made by officers and employees rather than discharge their own obligation to deliberate over important institutional matters. ${ }^{74}$ By default, this dynamic transfers authority from the board of directors to the charity's officers; although officers nominally report to the board, in practice, they often enjoy near absolute control over the charity, wield great influence over the board itself, and receive salaried compensation. ${ }^{75}$ Salaried officers,

titled to vote on matters of governance and operation, but the vast majority of charities opt not to grant membership voting rights. See, e.g., James J. Fishman and Stephen Schwarz, Nonprofit Organizations: Case and Materials 58 (Foundation Press 4th Ed. 2010) ("Most public benefit corporations have no members and are governed by self-perpetuating boards of directors.").

71. RichaRD A. POSNER, ECONOMIC ANALYSIS OF LAW § 18.5, at 698 (8th ed. 2010) (“[The] board of trustees [of a charitable foundation] is self-perpetuating and is accountable to no one for the performance of the enterprise. (Although state attorneys general have legal authority over the administration of charitable trusts, it is largely informal.)").

72. See National Committee for Responsive Philanthropy, Criteria for Philanthropy at Its Best: Benchmarks to Assess and Enhance Grantmaker Impact, page 62. Available at http://www.ncrp.org/p aib. ("Recent studies indicate that foundation staffs, particularly program officers, are becoming more diverse, but the same cannot be said of boards. This means that decision-making remains concentrated in the hands of a homogeneous group at most foundations."); Panel on the Nonprofit Sector, Report to Congress and the Nonprofit Sector on Governance, Transparency, and Accountability (2005), page 71. Available at http://www.nonprofitpanel.org/Report/index.html. ("The founders of a nonprofit corporation may initially turn to family members, business partners, even neighbors and friends to serve on the board of directors. Finding independent board members can be a particular problem in smaller communities and rural areas. Nonetheless, the effort to find independent members is important to the long-term success and accountability of the organization and should be a legal requirement for public charities that are eligible to receive tax-deductible contributions on the most favorable terms."); Panel on the Nonprofit Sector, Principles for Good Governance and Ethical Practice: A Guide for Charities and Foundations (2007), available at https://www.independentsector.org/uploads/Accountability_Documents/Princ iples_for_Good_Governance_and_Ethical_Practice.pdf ("The founders of a nonprofit corporation sometimes initially turn to family members and business partners to serve on its board of directors, but interlocking financial relationships can increase the difficulty of exercising the level of independent judgment required of all board members.").

73. See Katherine O'Regan and Sharon M. Oster, Does The Structure and Composition of The Board Matter?; The Case of Non-Profit Organizations, 21 J.L. ECON. \& ORG. 205, 215 (2005) (nonprofit boards are typically composed of volunteer directors who devote less time to board service than their for-profit counterparts); James J. Fishman, Standards of Conduct for Directors of Nonprofit Corporations, 7 PACE L. REV. 389, 396 (1986) ("Directors are sought for special skills or achievement; support of, or relationship to, the management; social or political connections; name recognition which provides the organization with added credibility particularly useful for fund raising efforts; status as beneficiaries of the organization's activities; or deep pockets - generous financial support.").

74. James J. Fishman, Standards of Conduct for Directors of Nonprofit Corporations, 7 PACE L. REV. 389, 395, 397 (1986)

75. Id. 
who have a personal interest in preserving and maximizing benefits from their own employment, have the opportunity to exploit lax board oversight to their own advantage at the charity's expense. To be sure, many charities are run by honest and responsible individuals who faithfully discharge their obligations with care, diligence and loyalty. That being said, the nonprofit form is structurally prone to high agency costs because principals are largely absent from institutional governance. ${ }^{76}$ As a result, negligent and self-dealing conduct can go undetected without remedy, thereby imposing adverse consequences on charitable beneficiaries and the taxpaying public that subsidizes charitable activity. ${ }^{77}$

In the absence of meaningful accountability, cases abound in which nonprofit fiduciaries have mismanaged or purloined their own charities, abuses that harm charitable beneficiaries and erode the public's investment in charitable assets. $^{78}$ The most egregious violations arise from breach of the duty of loyalty in which officers or directors engage in self-dealing transactions with the charity. ${ }^{79}$ Other types of fiduciary breach, while less newsworthy, can lead a charity into financial distress and insolvency. For example, the duty of prudence, a subset of the duty of care, mandates that fiduciaries diversify the charity's invested assets unless there is a compelling reason not to diversify. ${ }^{80}$ Failure to diversify invested assets exposes the charity to an unreasonable risk of loss that, in some cases, results in financial distress or insolvency. ${ }^{81}$ In one recent

76. To the extent charitable beneficiaries have an interest in enforcing fiduciary duties, the collective action problem decreases the likelihood that such a suit will be brought. See Terry Lynn Helge, Policing the Good Guys: Regulation of the Charitable Sector Through a Federal Charity Oversight Board, 19 CORNELl J. L. \& PUB. POL'Y 1, 46-47 (2009). For an excellent empirical study of agency costs, see Jonathan Klick \& Robert H. Sitkoff, Agency Costs, Charitable Trusts, and Corporate Control: Evidence from Hershey's Kiss-Off, 108 Colum. L. REV. 749 (2008) (quantifying \$850 million in agency costs arising from a charitable board's oversight of the Milton Hershey Trust).

77. See also James J. Fishman and Stephen Schwarz, Nonprofit Organizations: Case and Materials 221 (Foundation Press $4^{\text {th }}$ Ed. 2010) ("Because nonprofit outcomes may be harder to measure than forprofit counterparts, organizations may go on for years unobserved, undistinguished, unaccomplished, and largely unregulated.").

78. See, e.g., Marion R. Fremont-Smith and Andras Kosaras, Wrongdoing by Officers and Directors of Charities: A Survey of Press Reports 1995-2002, 42 EXEMPT ORG. TAX REV. 25 (2003) (documenting 152 cases of nonprofit officers who committed criminal offenses or breaches of the fiduciary duties of loyalty or care).

79. See, e.g., Edgewater Med. Ctr. v. Edgewater Prop. Co. (In re Edgewater Med. Ctr.), 373 B.R. 845,850 (Bankr. N.D. Ill. 2007) (unwinding fraudulent transfers and imposing punitive damages for breach of duty of loyalty by medical center's chief executive officer).

80. Under the Uniform Prudent Management of Institutional Funds Act § 3(e)(4), "An institution shall diversify the investments of an institutional fund unless the institution reasonably determines that, because of special circumstances, the purposes of the fund are better served without diversification." The comment to this subsection provides explains the duty to diversify: "Duty to Diversify. This subsection assumes that prudence requires diversification but permits an institution to determine that nondiversification is appropriate under exceptional circumstances. A decision not to diversify must be based on the needs of the charity and not solely for the benefit of a donor."

81. Cf., MARion FreEmont-Smith, Governing NonProfit Organizations, 432-33 (Harvard University Press 2004) ("There were a sufficient number of instances in the 1990s and early 2000s in which charities experienced severe losses from the failure to diversify to warrant concluding that the rule should be modified or at the least further clarified. Examples that were widely publicized involved Emory University, which was reported in 2000 to be invested disproportionately in Coca Cola stock; 
Charitable Insolvency and Corporate Governance in Bankruptcy Reorganization

instance, the Robert I. Lappin Charitable Foundation, a regional Massachusetts charity, invested most of its assets with Bernard Madoff and lost approximately $\$ 8$ million when the Ponzi scheme unraveled; the charity was forced to shut down, ${ }^{82}$ although it appears to have since reconstituted. ${ }^{83}$

Thus, financial distress is often (though not always) associated with poor corporate governance and the breach of fiduciary duties. Since charitable fiduciaries are commonly held harmless for damage caused by the breach of fiduciary duties, the only remedy available to the charity may be the removal of the officers and director's responsible for the charity's financial distress.

\section{FIDUCIARY ACCOUNTABILITY IN FinANCIALLy DistRESSED CHARITABLE INSTITUTIONS}

This Part argues that the charitable accountability problem becomes even more acute when a charity encounters financial distress or insolvency because marketplace systems and features of the Bankruptcy Code that tend to constrain corporate governance in for-profit entities fail to oust blameworthy charitable incumbents responsible for causing financial distress. Three constraints, in particular, tend to police corporate governance in distressed forprofit firms: (a) bank monitoring, (b) the absolute priority rule and the transfer of ownership and control, and (c) involuntary bankruptcy proceedings. In the charitable sector, however, those constraints are either entirely or largely absent. Consequently, blameworthy charitable fiduciaries are better positioned to entrench themselves and engage in self-serving opportunism when compared to their for-profit counterparts.

\section{A. Bank Monitoring and Intervention}

\section{For-Profit Sector Loan Covenants}

In large for-profit businesses, bank lenders play an important role in corporate governance, particularly when borrowers begin to slide into financial distress. ${ }^{84}$ Lenders generally do so through commercial lending agreements that

Temple University, which in 2000 had more than $50 \%$ of its portfolio in bonds; the Art Institute of Chicago, whose board approved an investment of almost $\$ 400$ million of its $\$ 650$ million endowment in hedge funds, with one particular investment of \$23 million reported in June 2001 to have nearly vanished and another \$20 million to be at risk; and the Packard Foundation, whose holding of stock in Hewlett Packard Company fell from \$13 billion in 1999 to $\$ 3.8$ billion as of October 2002."). See also Jonathan Klick \& Robert H. Sitkoff, Agency Costs, Charitable Trusts, and Corporate Control: Evidence from Hershey's Kiss-Off, 108 CoLUM. L. REV. 749 (2008).

82. http://www.jta.org/news/article/2008/12/15/1001552/north-shore-community-reels-from-lappinfoundation-collapse.

83 See http://www.rilcf.org/.

84. See, e.g., Frederick Tung, Leverage in the Board Room: The Unsung Influence of Private Lenders in Corporate Governance, 57 UCLA L. REV. 115, 119-120 (2009) ("It turns out, however, that bank creditors and other private lenders often enjoy significant oversight and influence over managerial deci- 
contain loan covenant provisions, which include the right to monitor the borrower's operation and intervene in the borrower's business before financial distress reaches the point of insolvency. Loan covenants help banks minimize the risk of default and, therefore, complement other forms of creditor protection, such as collateral pledged by the borrower as security. ${ }^{85}$ Loan covenants typically impose stringent performance benchmarks specifically tailored to the borrower's business to alert the lender of financial distress well before an actual payment default.$^{86}$ Loan covenants often require the borrower to produce a continuous stream of operational and financial information to the bank for monitoring purposes. ${ }^{87}$ To ensure compliance, banks employ full-time professionals to scrutinize the borrower's operational data for potential problems. ${ }^{88}$ Because banks reduce credit risk by monitoring for covenant violations, they have an incentive to detect mismanagement or "managerial slack" early and intervene

sions. Banks monitor investment, financing, and operational decisions as a matter of course. Banks not only constrain these managerial decisions but on occasion dictate them. The case of Warnaco offers a telling example. Warnaco's CEO was firmly entrenched. She chaired the board of directors and packed the board with her cronies. Yet when she faltered and the firm needed a significant infusion of new credit to continue operating, the CEO-friendly board could not resist lenders' call for new management. Though the hiring and firing of a firm's chief executive is the most crucial of board decisions, Warnaco's lenders effectively decided that question. Douglas Baird and Robert Rasmussen have accordingly dubbed private lender power the "missing lever" of corporate governance.").

85. In a recent empirical study of a large sample of for-profit companies, $79 \%$ of initial lending agreements were secured by a lien on the borrower's assets. Nini, Smith and Sufi, Creditor Control Rights, Corporate Governance, and Firm Value, SSRN Manuscript at 65 (table 1) (Dec. 2011), available at $\mathrm{http}: / /$ papers.ssrn.com/sol3/papers.cfm?abstract $\mathrm{id}=1344302$; Frederick Tung, Leverage in the Board Room: The Unsung Influence of Private Lenders in Corporate Governance, 57 UCLA L. REV. 115,125 (2009).

86. Loan covenants generally fall into one of the three categories: Affirmative covenants require the borrower to take certain actions, such as meeting GAAP standards of accounting, submitting financial information to the lender on a timely basis, meeting all regulatory reporting demands, paying taxes, maintaining equipment, buying insurance, and remaining in compliance with the law. Negative covenants prevent the borrower from taking certain actions, such as altering the fundamental nature of the business, changing control of the company (including through acquisition), disposing of assets, making excessive capital expenditures, and paying dividends. Financial covenants are accounting-based risk and performance limits. These covenants often consist of restrictions on a company's leverage, interest coverage, total fixed charges (including, for example, interest, rent, and capital expenditures), and net worth. Financial covenants almost always include a measure of periodic operating cash flow, such as earnings before interest, taxes, depreciation, and amortization (EBITDA). Nini, Smith and Sufi, Creditor Control Rights, Corporate Governance, and Firm Value, SSRN Manuscript at 6-7 (Dec. 2011), available at http://papers.ssrn.com/sol3/papers.cfm?abstract id=1344302 (emphasis in original). Nini, Smith and Sufi, Creditor Control Rights, Corporate Governance, and Firm Value, SSRN Manuscript at 16-17 (Dec. 2011) available at http://papers.ssrn.com/sol3/papers.cfm?abstract_id=1344302 (“[C]ovenant violations are quite common even for firms that are far from insolvent and not on the verge of payment default or bankruptcy. Contractual covenant levels are clearly set to be tripped well before severe financial distress, and violations typically are not resolved by means of bankruptcy, liquidation, or merger.").

87. See Frederick Tung, Leverage in the Board Room: The Unsung Influence of Private Lenders in Corporate Governance, 57 UCLA L. REV. 115, 132 (2009) ("Private lending agreements and institutional arrangements enable the lender to receive a continuous stream of information concerning the borrower's operating performance and financial condition. For example, in addition to regular financial reports and wide discretionary access to the borrower's books and records, properties, and management, a private lender often enjoys the ability to monitor a borrower's cash flows in real time as part of the lender's provision of cash management services to the borrower. This window gives the lender constant updates on the borrower's performance.").

88. Id. at 132-33. 
Charitable Insolvency and Corporate Governance in Bankruptcy Reorganization

before the borrower encounters severe financial distress. ${ }^{89}$ A covenant violation triggers a bank's right to demand immediate repayment of all outstanding debt, a provision known as loan acceleration..$^{90}$ This enables banks to play an influential role in corporate governance once a covenant violation occurs. Instead of accelerating the loan, banks typically forebear in exchange for voluntary concessions from the borrower, such as replacement of some or all of the existing management team. ${ }^{91}$ The right to demand full repayment upon violating a covenant places banks in a powerful position to exercise control over their borrower counterparties..$^{92}$

Some scholars argue that bank monitoring and intervention is often more effective at preventing financial distress than oversight by the borrower's own corporate board of directors. Banks often have industry expertise and the ability to evaluate the borrower's performance in comparison to other businesses in the same industry; corporate directors, on the other hand, may serve on the board of only a single corporation in a single industry and, therefore, lack the scope of knowledge necessary to assess the corporation's performance. ${ }^{93}$ Banks have strong financial incentives to scrutinize corporate governance because the repayment of principal depends on the borrower's continued solvency; corporate directors, by contrast, have weaker incentives to engage in monitoring activities unless they have substantial personal equity investments in the company. ${ }^{94}$ Banks are often better suited to intervene when the borrower's performance starts to decline because a covenant violation triggers an immediate right to accelerate; board intervention, conversely, requires directors to overcome the collective action problem and potential opposition from individual directors who are personally beholden to incumbent corporate managers. ${ }^{95}$

As for-profit businesses approach the point of insolvency, bank lenders tend to acquire even greater control over the borrower's corporate governance by supplying additional secured debt; this gives banks additional secured interests in bankruptcy that can be used as leverage to insist on the removal of incum-

89. Id. at 127 .

90. See, e.g., Nini, Smith and Sufi, Creditor Control Rights, Corporate Governance, and Firm Value, SSRN Manuscript at 7 (Dec. 2011) available at http://papers.ssrn.com/sol3/papers.cfm?abstract_id=13 44302.

91. See, e.g., id.

92. As Professors Baird and Rasmussen explain, "These loan agreements define defaults in ways that give creditors as much control over the board and its decisions as shareholders. Indeed, in the limit, these covenants can obliterate the difference between debt and equity. The line between debt and equity is an entirely permeable one, in terms of both cash flow rights and control rights. . . Rights that we ordinarily associate with shareholders, such as the right to elect members of the board or veto sales of the business, often reside elsewhere.” Douglas G. Baird \& Robert K. Rasmussen, Private Debt and the Missing Lever of Corporate Governance, 154 U. PA. L. REV. 1209, 1217 (2006).

93. Frederick Tung, Leverage in the Board Room: The Unsung Influence of Private Lenders in Corporate Governance, 57 UCLA L. REV. 115, 133-34 (2009).

94. Id. at 133.

95. Id. at 134. 
bent fiduciaries as a condition of reorganization. In a recent empirical study of large for-profit corporate bankruptcy reorganizations, scholars found that distressed businesses experienced a "dramatic change in capital structure" wherein the value of corporate assets declined substantially and the amount of secured debt increased substantially. ${ }^{96}$ Seventy-five percent of distressed businesses obtained additional secured financing shortly before filing for bankruptcy by opening a "prepetition credit facility." ${ }^{97}$ Of those businesses that obtained prepetition credit facilities, ninety-seven percent had loans secured by liens on all the company's assets..$^{98}$ The heightened use of secured prepetition credit facilities on the eve of bankruptcy is significant because, once the borrower files for bankruptcy, the borrower cannot obtain additional secured financing without the senior lender's consent, and lenders are, therefore, unlikely to extend credit to a borrower in financial distress without a secured interest. ${ }^{99}$ In other words, once the borrower files for bankruptcy, it is effectively precluded from taking on more debt without the senior secured lenders' consent. This vests the senior lender with substantial control over the debtor because it can withhold consent until the debtor agrees to replace blameworthy incumbents. In a large empirical study of secured prepetition credit facilities, eighty percent of chief executive officers were replaced during the four-year period commencing two years before the bankruptcy filing. ${ }^{100}$ According to the study's authors, this high turnover rate "is undoubtedly an underestimate . . because we did not look systematically for post-petition turnover." 101 Although there are many potential reasons for CEO turnover, the authors argue that senior lenders exercise pervasive control over the borrower's corporate governance during times of financial distress. ${ }^{102}$ The authors conclude that incumbent "managers are not able to use Chapter 11 as a safe harbor when their firms encounter financial distress." 103 Other empirical studies confirm that when for-profit companies go through bankruptcy reorganization, incumbent managers have a markedly higher rate of attrition. ${ }^{104}$

96. Kenneth M. Ayotte and Edward R. Morrison, Creditor Control and Conflict in Chapter 11, $1 \mathrm{~J}$. LEG. ANAL. 511, 518 (2009) ("we [saw] a 35 percent drop in asset value and an eleven-fold increase in secured debt among public companies during the one to two years preceding the bankruptcy filing.").

97. Id. at 522-523.

98. Id. at 513.

99. Id. at 523. ("If all of a firm's assets are encumbered by liens, it cannot obtain additional secured financing in bankruptcy without obtaining permission from or offering adequate protection to the prepetition secured lender.").

100. Kenneth M. Ayotte and Edward R. Morrison, Creditor Control and Conflict in Chapter 11, $1 \mathrm{~J}$. LEG. ANAL. 511, 522 (2009).

101. Id.

102. Id.

103. Id.

104. See Lynn M. LoPucki \& William C. Whitford, Corporate Governance in the Bankruptcy Reorganization of Large Publicly Held Companies, 141 U. PA. L. REV. 669, 723-38 (1993) (empirical study of management turnover among large for-profit business debtors following bankruptcy reorganization revealed a high rate of turnover compared to large businesses not in financial distress); Stuart C. Gilson, 
Charitable Insolvency and Corporate Governance in Bankruptcy Reorganization

Empirical studies in the for-profit business context show that when banks actively engage in covenant monitoring, agency costs decrease and firm enterprise valuations increase. ${ }^{105}$ Other studies show that when creditors intervene at the earliest stages of financial distress, borrowers are more likely to adopt conservative fiscal reforms and improve operational performance. ${ }^{106}$ In fact, enterprise value tends to increase when a for-profit firm violates a loan covenant-a result perhaps explained by the market's expectation of bank intervention in corporate governance. ${ }^{107}$

Importantly, one of the most common forms of intervention following a covenant violation is the removal of ineffective corporate managers-CEO attrition is highly correlated with bank intervention. ${ }^{108}$ Bank monitoring and intervention are, therefore, powerful constraints on incumbency entrenchment in large for-profit firms. Because bank intervention is highly correlated with a change in senior management suggests that, in the for-profit sector, those responsible for the borrower's financial distress are often removed as a matter of course.

\section{Charitable Borrowing Patterns}

In the charitable nonprofit sector, bank oversight is arguably less likely to constrain corporate governance because charities appear less likely to rely on credit facilities governed by loan covenants as a substantial source of financing. Empirical scholarship, while scarce, suggests that charities prefer to draw from internal capital sources rather than seek external debt financing from outside sources. If this is true, then bank monitoring and intervention in corporate gov-

Management Turnover and Financial Distress, 25 J. FIN. ECON. 241, 247 tbl. 3 (1989); Ethan S. Bernstein, All's Fair in Love, War \& Bankruptcy?: Corporate Governance Implications of CEO Turnover in Financial Distress, 11 STAN. J.L. BUS. \& FIN. 299, 308-09 (2006).

105. See Joanna M. Shepherd, Frederick Tung \& Albert H. Yoon, What Else Matters for Corporate Governance?: The Case of Bank Monitoring, 88 B.U. L. ReV. 991, 996 (2008) ("Our results suggest that (a) for a given quality of corporate governance, free cash flow in the presence of bank monitoring improves firm value; and (b) bank monitoring may matter most when strong entrenchment would otherwise encourage managers to squander free cash - i.e., when agency costs are high.").

106. Nini, Smith and Sufi, Creditor Control Rights, Corporate Governance, and Firm Value, SSRN Manuscript at 3 (Dec. 2011), available at http://papers.ssrn.com/sol3/papers.cfm?abstract_id=1344302 (empirical study of publicly traded companies that reported violations of a contractual covenant imposed by a lender).

107. Id. at 31 (concluding that "increases in creditor influence on the governance of the firm represents an optimal shift in control rights to the party that has the most incentive to monitor and influence the firm when it is performing poorly. This control shift has a positive knock-on effect that benefits equity-holders even as the creditors move to protect their own claims.").

108. Sadi Ozelge and Anthony Saunders, The Role of Lending Banks in Forced CEO Turnovers, SSRN Manuscript at 30 (concluding that creditors play a role in ousting underperforming CEOs following covenant violations); Smith and Sufi, Creditor Control Rights, Corporate Governance, and Firm Value, SSRN Manuscript at 33 (Dec. 2011), available at http://papers.ssrn.com/sol3/papers.cfm?abstract id=1344302 ("We offer evidence that firms in violation of a covenant in a private debt agreement change senior management, become more conservative in their financial and investment policy, and improve performance."). 
ernance would be less common than in the for-profit sector. If charities as a group are less likely to incur debt financing as compared to their for-profit counterparts, charities are more susceptible to incumbency entrenchment because lenders are less likely to be a catalyst for managerial turnover.

No published study has documented the prevalence of loan covenants in the charitable sector; however, empirical research on borrowing activity in the charitable sector suggests that charities tend to avoid debt financing in their capital structure. Most scholarship draws on data published by the Internal Revenue Service's Statistics of Income Program, which provides aggregate information about liabilities incurred by charities as reported on the annual Form 990 disclosure. ${ }^{109}$ Form 990 requires charities to disclose liabilities broken down into various categories; ${ }^{110}$ three of those categories - tax-exempt bond liabilities, secured mortgages and notes payable to unrelated third parties, and unsecured notes and loans payable to unrelated third parties - represent financial debt drawn from external sources for capital funding purposes. ${ }^{111}$ Multiple empirical studies using this data have concluded that a minority of charities rely on external forms of financial debt: cs.

109. http://www.irs.gov/uac/SOI-Tax-Stats-Charities-and-Other-Tax-Exempt-Organizations-Statisti

110. IRS Form 990 requires charities subject to the annual reporting mandate to itemize liabilities in each of the following nine categories: (1) accounts payable and accrued expenses; (2) grants payable; (3) deferred revenue; (4) tax-exempt bond liabilities; (5) escrow or custodial account liabilities; (6) payables to current and former officers, directors, trustees, key employees, highest compensated employees, and disqualified persons; (7) secured mortgages and notes payable to unrelated third parties; (8) unsecured notes and loans payable to unrelated third parties; and (9) other liabilities (including federal income tax, payables to related third parties, and other liabilities not otherwise included), available at http://www.irs.gov/pub/irs-pdf/f990.pdf at 11.

111. See, e.g., Marc Jegers and Ilse Verschueren, On the Capital Structure of Non-Profit Organisations: An Empirical Study for Californian Organisations, 22 FinANCIAL ACCOUNTABILITY \& MANAGEMENT 4, 309 at 315-16 (2006) (drawing the distinction between all liabilities ("accounts payable, accrued expenses, grants payable, deferred revenues, nonmarket debt from officers, directors, trustees and key employees, tax-exempt bonds, mortgages and other notes payable, other liabilities") and financial debt ("tax-exempt bonds, mortgages and other notes payable."). 
Charitable Insolvency and Corporate Governance in Bankruptcy Reorganization

\begin{tabular}{|c|c|c|c|c|}
\hline Author & $\begin{array}{l}\text { Year of Data } \\
\text { Collection }\end{array}$ & $\begin{array}{c}\text { Sample } \\
\text { Size (\# of } \\
\text { charities) }\end{array}$ & $\begin{array}{c}\text { Sample } \\
\text { Characteris- } \\
\text { tics }\end{array}$ & $\begin{array}{l}\text { \% of Charities } \\
\text { Reporting Fi- } \\
\text { nancial Debt }\end{array}$ \\
\hline Calabrese $^{112}$ & $1998-2003$ & 427,041 & $\begin{array}{c}\text { National } \\
\text { sample of } \\
\text { non-religious } \\
\text { charities }\end{array}$ & $37 \%$ \\
\hline $\begin{array}{c}\text { Jegers \& } \\
\text { Verschueren } \\
113\end{array}$ & 1999 & 22,766 & $\begin{array}{c}\text { California } \\
\text { sample of } \\
\text { non-religious } \\
\text { charities }\end{array}$ & $18 \%$ \\
\hline $\begin{array}{c}\text { Yan, } \\
\text { Denison, } \\
\text { Butler }^{114}\end{array}$ & 2000 to 2003 & 1,387 & $\begin{array}{c}\text { National } \\
\text { sample of } \\
\text { charities de- } \\
\text { voted to arts, } \\
\text { culture, and } \\
\text { humanities }\end{array}$ & $44.1 \%$ \\
\hline Denison $^{115}$ & 2004 & 14,887 & $\begin{array}{c}\text { National } \\
\text { sample of } \\
\text { non-religious } \\
\text { charities }\end{array}$ & $\begin{array}{l}45.87 \% \text { reported } \\
\text { secured mort- } \\
\text { gages and notes } \\
\text { payable to unre- } \\
\text { lated third par- } \\
\text { ties } \\
20.92 \% \text { reported } \\
\text { tax-exempt bond } \\
\text { liabilities } 116\end{array}$ \\
\hline
\end{tabular}

The Denison study illustrates that charities are more likely to incur mortgage debt than bond debt and that, when broken down by category, charities in the fields of health and education are far more likely than other types of charities to seek external debt financing. ${ }^{117}$ This makes sense because hospitals and

112. Thad D. Calabrese, Testing Competing Capital Structure Theories of Nonprofit Organizations, 31 J. OF PuB. Budgeting \& Fin. 137 (2011).

113. Marc Jegers and Ilse Verschueren, On the Capital Structure of Non-Profit Organisations: An Empirical Study for Californian Organisations, 22 FinANCIAL ACCOUNTABILITY \& MANAGEMENT 309, at 321 (2006).

114. Yan, Denison \& Butler, Revenue Structure and Nonprofit Borrowing, 37 PuBLIC FinANCE REVIEW 60 (2009).

115. Dwight V. Denison, Which Nonprofit Organizations Borrow?, 29 J. PuB. Budgeting \& Fin. 110 , at 118 (2009).

116. The 2004 Denison study isolated financial debt into two categories: secured mortgages and notes payable to unrelated third parties and tax-exempt bond liabilities.

117. Dwight V. Denison, Which Nonprofit Organizations Borrow? 29 J. PUB. Budgeting \& Fin. 
universities are often large enough and have sufficiently stable sources of revenue to justify and attract external sources of debt financing. Charities that do obtain capital through external debt financing tend to be larger nonprofit organizations and rely on financing in the form of mortgages and tax-exempt bonds. ${ }^{118}$ Although it is theoretically possible for mortgages and tax-exempt bonds to be accompanied by loan covenants, mortgagees and bondholders do not appear to play much if any role in charitable governance. ${ }^{119}$

Consistent with the above empirical studies, corporate finance scholarship in the area of capital structure theory predicts that charitable nonprofit organizations are less likely to borrow when compared to their for-profit counterparts. ${ }^{120}$ Capital structure theory suggests that charities prefer to avoid external credit facilities for at least two reasons: (1) the tax-exempt status of charitable nonprofit organizations minimizes or eliminates the tax savings achieved by forprofit firms that benefit from deducting interest as a business expense; and (2) charities tend to be risk averse and the use of debt financing increases the risk of default. ${ }^{121}$ Some scholars also suggest that charities avoid debt financing, not by preference, but because they often lack collateral to offer lenders as security. ${ }^{122}$ Charitable assets are often intangible or subject to donor-imposed re-

110, at 118 (2009). In Denison's study, 21\% of all charities reported bond liabilities, but when broken down by category, $39 \%$ of health related charities and $30 \%$ of education related charities reported bond liabilities.

118. Id. at 110 .

119. In subsequent research, I plan to investigate empirically the role loan covenants in mortgage debt and bonds issued by charitable nonprofit organizations.

120. Corporate and public finance scholars have published a small but growing body of literature on charitable borrowing patterns with a particular focus on capital structure, a term that refers to the combination of retained earnings, debt, and equity used by a firm to finance its operations. See Woods Bowman, The Uniqueness of Nonprofit Finance and the Decision to Borrow, 12 NONPROFIT MGMT. AND LEADERSHIP 298 (2002). Scholars have applied capital structure theory, originally developed in the forprofit firm context, to predict whether and when charities are likely to include debt financing as part of their capital structure. Thad D. Calabrese, Testing Competing Capital Structure Theories of Nonprofit Organizations, 31 J. PUB. BUdGETING \& FIN. 121 (2011) ("Although nonprofit organizations lack investors and paid-in capital, they do have donors who might provide an organization with capital (contributions); unlike an investor, however, a donor cannot remove past donations and does not expect to receive a future financial return (such as a dividend) from the nonprofit."); see also Woods Bowman, The Uniqueness of Nonprofit Finance and the Decision to Borrow, 12 NONPROFIT MGMT. AND LEADERSHIP, at 298 (2002) (applying capital structure theory to charitable nonprofit borrowing patterns); Yan, Denison \& Butler, Revenue Structure and Nonprofit Borrowing, 37 Public Finance Review, at 49 (2009) (applying capital structure theory to charitable nonprofit borrowing patterns); Dwight V. Denison, Which Nonprofit Organizations Borrow?, 29 J. PuB. BudgeTING \& FIN. 113 (2009) (applying capital structure theory to charitable nonprofit borrowing patterns). The two dominant theories of capital structure - pecking order theory and static trade-off theory - both assume that corporate managers always favor the capital structure with the lowest overall cost (i.e., "cheaper per dollar raised"); the theories diverge on whether capital structure decisions are driven by the tax consequences associated with debt financing. See Woods Bowman, The Uniqueness of Nonprofit Finance and the Decision to Borrow, 12 Nonprofit Management and Leadership 298 (2002).

121. See, e.g., Thad D. Calabrese, Testing Competing Capital Structure Theories of Nonprofit Organizations, 31 J. PUB. BUdGETING \& FIN. 131 (2011).

122. See George G. Triantis, Organizations as Internal Capital Markets: The Legal Boundaries of Firms, Collateral, and Trusts in Commercial and Charitable Enterprises, 117 HARV. L. REV. 1102, 1153 (2004); Marc Jegers and Ilse Verschueren, On the Capital Structure of Non-Profit Organisations: 
Charitable Insolvency and Corporate Governance in Bankruptcy Reorganization

strictions that preclude creditor collection in bankruptcy. ${ }^{123}$ This lack of collateral makes it more difficult and expensive for charities to obtain external debt financing. ${ }^{124}$

The relative infrequency of debt financing and loan covenant agreements within the charitable sector illustrates that financial creditors do not participate as vigorously in monitoring and influencing corporate governance as they do in the for-profit sector. As explained above, banks appear at least somewhat effective at using loan covenant agreements to police managerial slack and remove underperforming managers in for-profit firms. ${ }^{125}$ Banks insist on their debtors maintaining good corporate governance, not because it furthers the public interest, but because well-governed debtors are more likely to remain solvent and repay the debt. Thus, by pursuing their own interests in maintaining creditworthy borrowers, bank creditors that monitor and intervene in the corporate governance of their borrowers engage in activities that inure to the benefit of the borrower's other stakeholders. When bank creditors are absent from the picture - as is frequently the case in the charitable sector-managerial agency costs increase as does the likelihood that blameworthy incumbent fiduciaries will remain in place post-bankruptcy, even when at fault for causing the charity's condition of financial distress.

\section{Donor Participation in Charitable Governance}

Although most charities are free from creditor monitoring and intervention, institutional charitable donors sometimes reserve the right to participate in corporate governance by imposing gift restrictions similar to loan covenants imposed by banks in the for-profit context. Those restrictions can include the right to monitor the charity's internal operations and revoke the gift under specified circumstances. In theory, donors could be expected to play a positive role in charitable oversight because their generosity suggests a genuine interest in the charity's mission, and by extension, concern for the financial health and governance of the charitable donee. In practice, however, even the most sincere donors tend to be far less competent than banks at monitoring for financial distress; individual donors are also typically driven to intervene in charitable governance matters for personal reasons rather than to protect the public interest. ${ }^{126}$

An Empirical Study for Californian Organisations, 22 Financial Accountability \& Management 310 (2006) ("[A]lmost half of the [nonprofit organizations] in our sample show no debt at all, indicating that in a lot of circumstances financial institutions and creditors are reluctant to lend any money to [nonprofit organizations], be it as a formal loan or as credit sales.")

123. Thad D. Calabrese, Testing Competing Capital Structure Theories of Nonprofit Organizations, 31 J. Pub. Budgeting \& Fin. 131 (2011).

124. Id. ("Theory suggests that lenders are more willing to extend credit when there are durable assets that serve as collateral, since bankruptcy costs are lower.").

125. See supra, Part III.A.1 .

126. See Reid K. Weisbord \& Peter DeScioli, The Effects of Donor Standing on Philanthropy: In- 
To illustrate this concept, consider a detailed example in which one large institutional donor imposed stringent covenant-like restrictions but was unsuccessful in averting (or arguably attempting to avert) a large charity's bankruptcy: In 2003, the Annenberg Foundation awarded the Philadelphia Orchestra a $\$ 50$ million grant following a decades-long relationship between the Orchestra and Walter and Lenore Annenberg. ${ }^{127}$ The grant established an endowment to provide the Orchestra with annual income for educational programming, domestic and international touring, special artistic endeavors, and disseminating the Orchestra's performances through electronic media. ${ }^{128}$ The grant established a charitable endowment that gave the Orchestra a right to income but not principal. ${ }^{129}$ The Orchestra agreed to the following: not to commingle the grant funds with other assets except for investment purposes; not to deduct administrative or overhead charges except for third-party investment management fees; to refer to the funds as the "Annenberg Endowment Funds" in its books; to "make a strong good faith effort" to raise an additional $\$ 50$ million for its endowment by June 30, 2008; to submit an annual "narrative report" to the Annenberg Foundation regarding its use of the funds and fundraising progress; and to recognize the gift "in perpetuity in the program book distributed at every performance." 130

The agreement contained stringent covenant-like restrictions, including a requirement that the Orchestra maintain a balanced annual operating budget. ${ }^{131}$ If the Orchestra incurred an operating deficit, then the Foundation was entitled to declare a material breach. ${ }^{132}$ To ensure compliance, the Foundation required

sights from the Psychology of Gift-Giving, 45 GONZ. L. REV. 225, 281-87 (2010).

127. The Orchestra made several proposals to the Annenberg Foundation before receiving the grant. The Orchestra's written proposals were originally attached as exhibits to the Grant Agreement and expressly incorporated by reference, but were not included in the exhibit filed by the Annenberg Foundation on the bankruptcy docket. Grant Agreement, Limited Objection of the Annenberg Foundation, Ex. A, p. 1, In re Philadelphia Orchestra Ass'n, Doc. No. 478, Case No. 11-13098 (E.D. Pa. Bank. Oct. 13, 2011).

128. Id. The original grant of $\$ 50$ million, payable in $\$ 10$ million annual installments from 2003 to 2007, established four limited-purpose funds for education ( $\$ 15$ million), touring ( $\$ 15$ million), artistic endeavors ( $\$ 10$ million), and media and technology ( $\$ 10$ million).

129. The grant agreement entitled the Orchestra to "Spendable Income," defined as "the amount made available for annual expenditure from each Fund in accordance with the Orchestra's draw policy under its Endowment Fund Investment Policy," but not to exceed 6.25\% in the first year and $5.5 \%$ in subsequent years. Unused Spendable Income could be carried forward. The agreement prohibited the Orchestra from allocating Spendable Income "for or against any union matter of any kind or any matters related thereto ... directly or indirectly, under any circumstances." Id. at 5-6.

130. Id. at 6-7.

131. The agreement defined balanced annual operating budget as follows: "The annual operating budget for each fiscal year will be considered 'balanced' only if, based upon generally accepted accounting principles, it reflects that the total of (1) all operating revenues and (2) Spendable Income from unrestricted, temporarily restricted and permanently restricted endowment funds, equals or exceeds operating expenses (excluding depreciation)." Operational surplusage could be carried forward to the following year for purposes of complying with the balanced budget requirement. Id. at 8 .

132. The grant agreement defined "operating deficit" as "the excess of the actual operating expenses (excluding depreciation) over the total of (1) all operating revenues and (2) Spendable Income from unrestricted, temporarily restricted and permanently restricted endowment funds," of greater than $1.5 \%$." 
Charitable Insolvency and Corporate Governance in Bankruptcy Reorganization

the Orchestra to submit annual audited financial statements, certified summaries of operating performance, and an annual operating budget approved by the Orchestra's board of directors. ${ }^{133}$ Most notably, the Foundation made the grant expressly revocable upon the happening of certain adverse events (as determined by the Foundation's sole discretion):

a. The Orchestra becomes insolvent;

b. The Orchestra fails to meet on a current basis any of its material debts or obligations;

c. The taking of any material property of the Orchestra by official levy or execution;

d. The filing by the Orchestra for an appointment of a trustee, receiver, or liquidator;

e. The filing by the Orchestra of a voluntary petition in bankruptcy;

f. The filing by an individual or entity of an involuntary petition in bankruptcy against the Orchestra;

g. The loss of the Orchestra's tax-exempt status as a Section 501(c)(3) (or successor provision thereto) entity as defined by the Internal Revenue Code. . ;

h. The material breach by the Orchestra of any of the terms and limitations of this Agreement, which breach remains uncorrected for a period of sixty days after receipt by the Orchestra of a written notice from the Foundation which sets forth the alleged breach. ${ }^{134}$

Violation of any of above conditions allowed the Foundation to cancel all unpaid installments and demand the return of all disbursed funds. ${ }^{135}$ Likewise, liquidation of the Orchestra or its failure to perform "in Philadelphia as a group on a regular multiple performance basis" entitled the Foundation to the return of all funds. ${ }^{136}$ The grant agreement also contained a spendthrift clause to prevent the Orchestra's creditors from reaching the endowment principal, which stated: "Without limitation, no third party nor any of the Orchestra's creditors or any trustee in bankruptcy shall have any right or claim to the Funds or the proceeds or any part thereof by any purported assignments or transfer at any time. No other party may rely upon the terms and conditions of these Funds." 137

While the stringent, covenant-like provisions gave the Foundation leverage to intervene in the Orchestra's governance before it became insolvent, the Foundation did not appear to have exercised that leverage. In 2011, the Orches-

Id. at 8-9.

133. Id. at 7.

134. Id. at 11 .

135. Id.

136. Id. at 9.

137. Id. at 10 . 
tra filed for Chapter 11 reorganization following long-term financial problems ${ }^{138}$ and years of faltering leadership marked by simultaneous vacancies in key institutional positions (i.e., music director, president/chief executive, and chairman of the board of trustees). ${ }^{139}$ Before filing its petition, the Orchestra informed the Annenberg Foundation of its intent to pursue bankruptcy, so the Foundation received actual notice of the Orchestra's problems. ${ }^{140}$ After the Orchestra entered bankruptcy protection, the Foundation intervened in the proceeding for the limited purpose of protecting the restricted endowment from collection by creditors. At that point, the Foundation made public its intent to monitor the Orchestra's situation. ${ }^{141}$ In May 2012, after settling all contested claims in the bankruptcy proceeding, the Orchestra reached a new agreement with the Foundation that modified the original terms of the Grant Agreement. ${ }^{142}$ In particular, the new terms imposed additional requirements that the Orchestra cap its operating budget by limiting expenditures and raising additional funds from its board of directors. ${ }^{143}$ In addition, the amended agreement transferred the endowment's assets from the Orchestra's own trust account to a third-party trustee. ${ }^{144}$ In July 2012, the Orchestra emerged from bankruptcy and (fortunately) appears to be in the early stages of a full recovery. ${ }^{145}$

138. Declaration of Richard B. Worley, In re Philadelphia Orchestra Ass'n, Doc. No. 12, Case No. 11-13098 (E.D. Pa. Bank. Apr. 17, 2011) (describing a substantial decline in revenues and a simultaneous substantial increase in operating expenses); see also Richard B. Worley, Can Bankrupcy Fix Orchestra? Yes, it's the Best Chance, PHILADELPHIA INQUIRER, May 18, 2011, http://articles.philly.com/20 11-05-18/news/29556362 1 endowments-orchestra-financial-crisis.

139. Peter Dobrin, Eschenbach to bow out in 2008: Music Director will Leave after 5 Years with Orchestra, PHILADELPHIA INQUIRER, Oct. 21, 2006, at A01; Peter Dobrin, Orchestra Leadership in Flux, Financial Picture Gloomy, PhILADELPHIA InQuirer, Jan. 15, 2009, at D01; Peter Dobrin, Philadelphia Orchestra's Chairman Steps Down Early, PhILADELPHIA INQUIRER, Jan. 27, 2009, at C01; David Patrick Stearns, Associate Conductor's Departure not a Surprise, PHILADELPHIA INQUIRER, June 3, 2010, at D01; Peter Dobrin, Phila. Orchestra Musicians make Pay Concessions, PHILADELPHIA InQUIRER, Feb. 27, 2010, at B01 (reporting a marketing vice president vacancy).

140. Peter Dobrin, Orchestra's Bankruptcy Risks Forfeit of \$50M Gift, PHILADELPHIA INQUIRER, May 22, 2011. The Orchestra's president stated, "I previewed all of the issues and sought his counsel, and wanted to understand their current thinking [ . . . ] I think we've been good communicators, we've been thoughtfully engaged with them, and I think they understood the reasons." The Philadelphia Inquirer reported that she "continued to update the foundation as decisions regarding bankruptcy were made." Id.

141. See Limited Objection of the Annenberg Foundation, In re Philadelphia Orchestra Ass'n, Doc. No. 478, Case No. 11-13098 (E.D. Pa. Bank. Oct. 13, 2011) (objecting to a potential interpretation of the Orchestra's debtor-in-possession financing agreement that could potentially include restricted endowment funds as assets pledged for collateral). The Foundation's executive director told the Philadelphia Inquirer, "We're watching. Our trustees are voracious readers and are aware of the situation, but there's nothing actionable at this point." Peter Dobrin, Orchestra's Bankruptcy Risks Forfeit of \$50M Gift, PHILADELPHIA INQUIRER, May 22, 2011.

142. Peter Dobrin, Annenberg Foundation Tightens Rules on $\$ 50 M$ Given to Orchestra, PHILADELPHIA INQUIRER, May 30, 2012, http://www.philly.com/philly/entertainment/20120530_Annen berg_Foundation_tightens_rules_on_50M_given_to_orchestra.html\#ixzz1wP28ZkQE.

143. Id.

144. Id.

145. The Philidelphia Orchestra Ass'n Officially Emerges from Chapter 11 Effective July 30, 2012, PHILADELPHIA INQUIRER, July 31, 2012, http://www.philorch.org/press-room/news/philadelphiaorchestra-association-officially-emerges-chapter-11-effective-july-30. 
Charitable Insolvency and Corporate Governance in Bankruptcy Reorganization

The Philadelphia Orchestra's experience is consistent with anecdotal accounts of donors who bargain for the right to participate in a charity's internal affairs, but, unlike banks and lending institutions, are typically reticent to exercise that right to protect the charity. ${ }^{146}$ Although it is possible that the Foundation had been quietly monitoring and intervening in the Orchestra's governance in the years preceding the bankruptcy filing, there is no public information to suggest this occurred. To the contrary, circumstantial evidence suggests that the Foundation played little or no role in the Orchestra's pre-bankruptcy corporate governance even though the Foundation had the authority and leverage to do so. The Foundation never exercised its right to withhold income in years when the Orchestra failed to balance its budget - a notable fact given that the Orchestra ran budget deficits in some of the years before it filed for bankruptcy. The Foundation also waited until the near-conclusion of the Orchestra's bankruptcy proceeding to insist on amendments that imposed more stringent operational requirements and tightened the Foundation's control over the endowment funds. The Foundation's primary purpose in intervening in the bankruptcy proceeding appears to have been to protect the endowment funds from creditor collection. If so, this would be consistent with scholarship that suggests that donors tend to engage in litigation to protect their own interests rather than the public interest in charitable assets. ${ }^{147}$

One explanation for the lack of donor oversight is that donors do not share the same incentives as bank creditors in monitoring for financial distress. The Annenberg Foundation, for example, had considerably less risk at stake when it established the endowment fund compared to a hypothetical bank extending credit for the same amount for at least two reasons. First, the Foundation's grant was a charitable contribution rather than a loan. Whereas banks bargain for repayment of principal and interest, the Annenberg grant required neither. Thus, while the Foundation may have had philanthropic, civic, or moral motivations for monitoring the Orchestra's fiscal health, its financial stake was less direct and concrete when compared to a bank creditor entitled to repayment of borrowed capital. Second, unlike a bank loan with a principal amount of $\$ 50$ million, the Foundation never granted the Orchestra a beneficial interest in the $\$ 50$ million endowment principal. The agreement provided the Orchestra with only the right to receive income, leaving the Foundation in control over most of the asset.

Of course, none of this is intended to imply that the Annenberg Foundation had any obligation or duty to the Orchestra to monitor its financial condition. The point is that donor oversight is not necessarily an adequate substitute for

146. See, e.g., Carter G. Bishop, The Deontological Significance of Nonprofit Corporate Governance Standards: A Fiduciary Duty of Care Without a Remedy, 57 CATH. U. L. REV. 701, 711 (2008).

147. See Reid K. Weisbord \& Peter DeScioli, The Effects of Donor Standing on Philanthropy: Insights from the Psychology of Gift-Giving, 45 GONZ. L. REV. 225, 281-87 (2010). 
creditor monitoring and intervention following the violation of a contractual loan covenant. The Annenberg Foundation had the right to withhold income payments and revoke the grant, but does not appear to have asserted those rights in such a way as to maintain the Orchestra's solvency or avoid the need for bankruptcy reorganization. ${ }^{148}$ This example suggests that donors who reserve the right to participate in corporate governance through gift restrictions do not necessarily exercise the right efficaciously. ${ }^{149}$

\section{B. Charitable Accountability in Bankruptcy Reorganization}

Chapter 11 of the Bankruptcy Code tends to exacerbate the charitable accountability problem because features of the reorganization process that vet incumbent officers and directors in for-profit reorganizations are not applicable in charitable nonprofit reorganizations. As detailed below, the "absolute priority" rule does not explicitly apply and, as a result, charities are less likely to undergo a transfer of ownership and control. These distinctions amplify the charitable accountability problem because Chapter 11 creates its own problems of corporate governance by granting a great deal of control and influence to the debtor's incumbent managers. Without the absolute priority rule and the transfer of ownership and control, a bankruptcy reorganization lacks the constraints necessary to prevent charitable fiduciaries from entrenching themselves and engaging in self-serving opportunism at the charity's expense.

\section{Unique Problems of Corporate Governance in Bankruptcy Reorganization}

Special problems of corporate governance arise in bankruptcy reorganizations because Chapter 11 grants the debtor's incumbent managers substantial control over the reorganization process. Prior to Chapter 11's enactment in

148. The provision is not likely enforceable. See 11 U.S.C. $\S 365(b)(2)$.

149. Donors arguably have more leverage to constrain charitable governance when a bankrupt charity requires new capital to successfully reorganize. The Orchestra, for example, initiated a major fundraising campaign to finance its expenses during reorganization and place the institution in better financial health upon emerging from bankruptcy. Peter Dobrin, Philadelphia Orchestra campaign yields \$2.6 million, PHILADELPHIA INQUIRER, May 18, 2011, http://www.philly.com/philly/blogs/artswatch/Philadel phia-Orchestra-campaign-yields-26-million.html. A bankrupt charity's need to attract new donations could have a short-term positive influence on charitable governance. See Evelyn Brody, The Charity in Bankruptcy and Ghosts of Donors Past, Present, and Future, 29 SETON HALl Legis. J. 471, 524 (2005) ("More systemically, donors, members, and other constituencies of a charity that emerges from bankruptcy might force long-term structural changes in the constitution and oversight of the charity. Donors might even be satisfied with making unrestricted donations if they succeed in making the charity's financial affairs more transparent and subject to their input. At the other extreme, a major donor might make demands for disclosure of information, a seat on the board, or the charity's waiver of the donor's lack of standing to sue for specific performance of a gift restriction. Thus, more is at stake in a charity bankruptcy than the short-term financial health of the entity."); Geoffrey A. Manne, Agency Costs and the Oversight of Charitable Organizations, 1999 WIS. L. REv. 227, n.5 (1999) (“There is, of course, a competition for charitable dollars. This competition induces contributors to engage in some monitoring, and it creates some incentive for agents to behave."). 


\section{Charitable Insolvency and Corporate Governance in Bankruptcy Reorganization}

1978, bankruptcy law required the appointment of a third-party trustee to oversee the bankruptcy estate and operate the debtor's business for the duration of the proceeding. The trustee would often displace incumbent managers to prevent waste or abuse of the debtor's assets. ${ }^{150}$ While the bankruptcy trustee provided neutral supervision of the debtor's assets, the trustee typically lacked the firm-specific knowledge necessary to operate the debtor's business effectively during the reorganization proceeding. The Bankruptcy Code of 1978 abolished the mandatory appointment of bankruptcy trustees because the presumptive retention of incumbent managers enabled continuity of business during reorganization, which in turn, helped to maximize the debtor's going concern value. ${ }^{151}$

Under Chapter 11 as currently enacted, the debtor's incumbent managers have wide latitude of influence over the reorganization proceeding. As debtorsin-possession, incumbent managers automatically retain control over the debtor's assets, continue to operate the debtor's business unless the bankruptcy court orders otherwise, and have an exclusive right to propose the initial plan of reorganization. ${ }^{152}$ In the for-profit debtor context, some bankruptcy scholars

150. Professors Lynn LoPucki and William Whitford explain the history of the pre-Chapter 11 system:

Prior to 1939 , the structure for governance of reorganizing companies was much the same as it is today. Managers remained in office and played a major role in determining the course of the reorganization. Under the direction of William $\mathrm{O}$. Douglas, the Securities and Exchange Commission conducted a number of empirical studies of the operation of the reorganization process. The SEC concluded that managements responsible for the companies' problems tended to remain in office and act in a self-serving manner to the detriment of public investors.

In 1939, the system was reformed by providing that upon the filing of a reorganization case by a large, publicly held company, the company's management would be replaced by a court-appointed trustee. Perhaps predictably, the managements of ailing companies chose not to surrender their control to trustees. Chapter X of the Bankruptcy Act, which embodied the 1939 reforms, fell into disuse. Congress repealed chapter X in the "reform" of 1979.

Lynn M. LoPucki \& William C. Whitford, Corporate Governance in the Bankruptcy Reorganization of Large Publicly Held Companies, 141 U. PA. L. REV. 669, 674-75 (1993); 150. H.R. Rep. No. 595, 95th Cong., 1st Sess. 233 (1977); 150. 11 U.S.C. $\S \S 1107-1108,1121$ (b). As Judge Richard Posner observes:

The balance between management and senior creditors may be tilted too far toward management because of an asymmetry of bargaining power brought about by the rules of bankruptcy law. During the period in which the management has the exclusive right to propose a plan of reorganization, and while the plan is under consideration by the bankruptcy court, the secured creditors cannot levy on their collateral, nor can the other creditors force a liquidation. The creditors, in short, lack an "exit option" from negotiation over a plan of reorganization. The managers have such an option; they are free to quit the firm and seek work elsewhere. The more valuable that option, the better the terms they will demand from the creditors.

Richard Posner, Economic Analysis of Law at 549 (Aspen Eighth Ed. 2011). The asymmetry tilts in favor of management, although the market for distressed debt does give creditors an exit option - sale of the debt. 
have criticized the reorganization provisions of Chapter 11 for giving the debtor-in-possession too much control over the proceeding because it permits opportunism and entrenchment by the debtor's incumbent managers. ${ }^{153}$

Chapter 11's debtor-in-possession default rule solved the problem of business interruption but exposed the bankruptcy estate to inherent conflicts of interest between incumbent managers and stakeholders of the reorganized entity. Incumbent fiduciaries have a duty to maximize the debtor's going concern value, but that duty is often inconsistent with their personal interest in preserving their own employment and compensation. ${ }^{154}$ The conflict is particularly disa-

153. See, e.g., Michael Bradley and Michael Rosenzweig, The Untenable Case for Chapter 11, 101 YALE L.J. 1043, 1049-50 (1992) ("We believe that, insofar as corporate bankruptcies are concerned, the principal beneficiaries of Chapter 11 (excluding the legions of lawyers, accountants and financial advisors who earn substantial fees from bankruptcy reorganizations) are corporate managers. Chapter 11 , in other words, may be seen as a kind of management defensive tactic against corporate debtholders which, like certain antitakeover defensive measures, enhances management's wealth at the expense of corporate security holders. Chapter 11, like many takeover defensive measures, is justified by its supporters as a mechanism to preserve and protect valuable corporate assets. And as is the case with many takeover defenses, the data show that Chapter 11 preserves and protects the jobs of corporate managers, not corporate assets."); see also Edward S. Adams, Governance in Chapter 11 Reorganization: Reducing Costs, Improving Results, 73 B.U. L. REV. 581 (1993); Carlos J. Cuevas, The Myth of Fiduciary Duties in Corporate Reorganization Cases, 73 Notre Dame L. Rev. 385 (1998); David A. Skeel, Jr., Markets, Courts and the Brave New World of Bankruptcy Theory, 1993 WIS. L. REV. 465; Erica M. Ryland, Bracing for the "Failure Boom": Should a Revlon Auction Duty Arise in Chapter 11?, 90 COLUM. L. REV. 2255, 2258 (1990).

154. Professors Coleman and Woodruff explain, "[C]onflict can arise from the desire of directors and management to retain their jobs and maximize their compensation. If a proposed plan contemplates the distribution of the majority of the equity in the debtor to creditors, the debtor's directors and management will realize that, upon implementation of the plan, their employment will be controlled by these creditors (who, by virtue of their newly obtained equity majority, will control the election of directors and, in turn, the hiring of management by such directors). This realization may lead to favoritism to creditors in the plan formulation process, in an effort to stay in the creditors' good graces. Alternatively, if directors and management believe that they probably will be ousted by the creditors upon implementation of the plan, they may vote themselves 'golden parachutes' or other short-term benefits which will drain unnecessarily the resources of the reorganized company." Thomas Henry Coleman and David E. Woodruff, Looking Out For Shareholders: The Role of the Equity Committee in Chapter 11 Reorganization Cases of Large, Publicly Held Companies, 68 AM. BANKR. L.J. 295, 295-96 (1994); see also Martin J. Bienenstock, Conflicts Between Management and the Debtor in Possession's Fiduciary Duties, 61 U. CIN. L. REV. 543, 545-46 (1992). When pre-bankruptcy managers secure golden parachutes or retention contracts to advance their own interests at the expense of the company's, they breach the fiduciary duty of loyalty. Cf. Gaillard v. Natomas Co., 208 Cal. App. 3d 1250, 1267 (1989); see also Scott F. Norberg, Debtor Incentives, Agency Costs, and Voting Theory in Chapter 11, 46 KAN. L. REV. 507, 521 n.5 (1998) ("In insolvent widely held corporations, managers who are primarily interested in their employment and reputations may be inclined toward overly risky investment decisions, so as to reverse the firm's fortunes. Insolvency encourages previously risk averse managers to take unwarranted risks in order to turn around the company and save their job positions and reputations."). See, e.g., Official Comm. of Unsecured Creditors of Cybergenics Corp. ex rel. Cybergenics Corp. v. Chinery, 330 F.3d 548, 573 (3d Cir. 2003) ("[The debtor-in-possession system] immediately gives rise to the proverbial problem of the fox guarding the henhouse. If no trustee is appointed, the debtor- really, the debtor's management - bears a fiduciary duty to avoid fraudulent transfers that it itself made. One suspects that if managers can devise any opportunity to avoid bringing a claim that would amount to reputational selfimmolation, they will seize it. For that reason, courts and commentators have acknowledged that the debtor-in-possession often acts under the influence of conflicts of interest.") (Citation and internal quotation omitted). See also Robert K. Rasmussen, The Ex Ante Effects of Bankruptcy Reform on Investment Incentives, 72 WASH. U. L. Q. 1159, 1173 (1994) (“To the extent that the payoffs to managers turn on their receipt of salary, managers have an incentive to entrench themselves. Financial distress often results in managers losing their jobs. Managers thus prefer decisions that protect them from the conse- 


\section{Charitable Insolvency and Corporate Governance in Bankruptcy Reorganization}

bling when incumbent fiduciaries have engaged in negligent or wrongful conduct that contributed to the debtor's state of insolvency because the debtor's going concern value would most likely be maximized by their removal. To mitigate those conflicts, Chapter 11 imposes fiduciary duties on the debtor-inpossession: incumbent fiduciaries owe all impaired creditors a duty to protect the bankruptcy estate's assets and maximize value. ${ }^{155}$ In practice, however, those duties are incredibly difficult to enforce. ${ }^{156}$ As a result, fiduciary duties under Chapter 11 are largely putative, and bankruptcy stakeholders tend to view enforcement litigation as an inefficient way of protecting their interests. ${ }^{157}$ Indeed, one scholar describes the lack of fiduciary enforcement in bankruptcy reorganization as "the black hole effect." ${ }^{\text {158 }}$ Debtor-in-possession fiduciary

quences of such distress, even though such decisions may not increase the value of the firm."). The moral hazard problem faced by individuals who control the DIP in bankruptcy reorganization has been discussed extensively in the literature. See, e.g., Scott F. Norberg, Debtor Incentives, Agency Costs, and Voting Theory in Chapter 11, 46 KAN. L. REV. 507, 509 n.5 (1998) (collecting authorities).

155. Commodity Futures Trading Comm'n. v. Weintraub, 471 U.S. 343, 355 (1985) (quoting Wolf v. Weinstein, 372 U.S. 633, 649-52 (1963)) ("[T] he willingness of courts to leave debtors in possession "is premised upon an assurance that the officers and managing employees can be depended upon to carry out the fiduciary responsibilities of a trustee."'); 11 U.S.C. $\S \S 1106-1107$. In re Mushroom Transp. Co., 382 F.3d 325, 339 (3d Cir. 2004) (duty to protect and preserve bankruptcy estate for the benefit of creditors). The fiduciary duties imposed by the Bankruptcy Code supplement the corporate fiduciary duties imposed on officers and directors under state law. Cf., David A. Skeel, Jr., Rethinking the Line Between Corporate Law and Corporate Bankruptcy, 72 TEX. L. REV. 471, 498 (1994).

The fiduciary duties imposed under Chapter 11 do not specifically prescribe or prohibit conduct, leaving courts to develop a body of common law. See Martin J. Bienenstock, Conflicts Between Management and the Debtor in Possession's Fiduciary Duties, 61 U. CIN. L. REV. 543, 551 (1992) ("Notably, there is no statutory federal law formulating the fiduciary duties of an insolvent company's management and directors.").

156. Martin J. Bienenstock, Conflicts Between Management and the Debtor in Possession's Fiduciary Duties, 61 U. CIN. L. REV. 543, 552 (1992) ("Management more interested in its own future than its creditors' may not be so crass as to prefer insiders and leave a paper trail to boot. Rather, management may operate 'by the book,' yet make key decisions, such as what plan to propose, based on considerations of which creditor classes would most likely retain management and approve the most lucrative management contracts. In this type of situation, everything is above board, yet some creditors are wrongfully impaired because management is looking out for themselves first. Moreover, there is no smoking gun and no witness will take the stand and testify that management's proposed plan is designed to obtain the best deal for management. To the contrary, management will produce many experts showing its new compensation arrangements are reasonable.").

157. See, e.g., Kelli A. Alces, Enforcing Corporate Fiduciary Duties in Bankruptcy, 56 KAN. L. REV. 83, 90 (2007) ("derivative suits tend to disappear under the control of DIP management, and are not an effective way to enforce the fiduciary duties corporate managers owe to the debtor"); David A. Skeel, Jr., Rethinking the Line Between Corporate Law and Corporate Bankruptcy, 72 TEX. L. REV. 471, 500 (1994) (shareholders rarely pursue derivative suits against corporate officers in bankruptcy); Lynn M. LoPucki \& William C. Whitford, Corporate Governance in the Bankruptcy Reorganization of Large Publicly Held Companies, 141 U. PA. L. REv. 669, 709 (1993) ("Moreover, even if the law of fiduciary duty provided shareholders or creditors with arguments as to whose interests management should serve, in the reorganization context it would largely be of only theoretical value. Suits by either creditors or shareholders against management for breach of fiduciary duty for actions taken by them during a reorganization case are rare.").

158. David A. Skeel, Jr., Rethinking the Line Between Corporate Law and Corporate Bankruptcy, 72 TEX. L. REV. 471, 500 (1994). Pre-petition equity holders have little incentive to pursue fiduciary enforcement litigation in bankruptcy because the corporation's insolvency reduces or eliminates their financial stake in any recovery. Id. at 500-01. Creditors opt not to pursue fiduciary enforcement litigation in bankruptcy because they have more direct remedies for self-dealing transaction by insiders, prefer- 
duties are, therefore, a weak constraint on incumbency entrenchment.

\section{Bankruptcy Constraints on Corporate Governance: Absolute Priority and the Transfer of Ownership and Control}

The bankruptcy reorganization process imposes primarily two constraints on the debtor-in-possession's ability to influence the reorganized entity: (1) the "absolute priority" rule and (2) the transfer of ownership and control of the debtor entity. Although these features of the reorganization process were not explicitly intended by Congress to constrain the conduct of corporate insiders, in for-profit reorganizations, they tend to curb the ability of incumbent officers and directors to engage in entrenchment and opportunism by subjecting their tenure to the discretion of unpaid creditors and owners of the reorganized debtor. Those features of the reorganization process, however, do not apply in the charitable nonprofit context.

The absolute priority rule embodies one of the central tenets of bankruptcy law that allocates losses to incumbent equity holders before creditors: creditors have an absolute right to be paid before incumbent investors receive any property (including stock) from the debtor's estate. ${ }^{159}$ The rule applies when a debtor seeks to confirm a plan over the dissent of unpaid creditors. Under Chapter 11, debtors have a first-mover advantage because they enjoy an exclusive right to propose the initial plan of reorganization ${ }^{160}$ and, thereafter, creditors have the right to vote on the debtor's proposed plan. ${ }^{161}$ If at least one class of creditors votes in favor, then the plan may be confirmed even if other creditor classes dissent. To obtain confirmation despite creditor dissent (a so-called "cram down" plan), the proponent must demonstrate to the bankruptcy court that the plan either provides for full repayment of dissenting creditors or satisfies the absolute priority rule. ${ }^{162}$ To satisfy the absolute priority rule, the proposed plan must extinguish all interests junior to those of the dissenting creditor class. Without the absolute priority rule, the debtor-in-possession would be able to dominate the reorganization proceeding and exert undue influence over key matters, such as whether to retain incumbent officers and directors.

The absolute priority rule prevents incumbent owners from using bankruptcy to eliminate liabilities without forfeiting ownership or control of the firm, an outcome that would "simply turn out to be too good a deal for the debtor's

ence and fraudulent conveyance actions. Id. at 504 .

159. 11 U.S.C. $\S \S 1129$ (a)(8), 1129(b)(2)(B)(ii); Case v. Los Angeles Lumber Products Co., 308 U.S. 106, 115-19 (1939); Norwest Bank Worthington v. Ahlers, 485 U.S. 197, 202 (1988) (the absolute priority rule ensures "that a dissenting class of unsecured creditors must be provided for in full before any junior class can receive or retain any property [under a reorganization] plan").

160. 11 U.S.C. $\$ 1121(\mathrm{~b})$

161. 11 U.S.C. $\S 1126$.

162. 11 U.S.C. $\S 1129(b)(2)(B)$. 
Charitable Insolvency and Corporate Governance in Bankruptcy Reorganization

owners." 163 This gives dissenting creditors important leverage in negotiating the terms of a proposed reorganization. By granting creditors the right to oppose a cram down plan preserving incumbent equity interests, the rule forces the debtor's incumbent owners to "buy" consent from dissenting creditors if they wish to retain an equity stake in the reorganized entity. This indirectly constrains corporate governance because incumbent officers and directors must also obtain creditor consent if they seek to remain in office after the debtor emerges from bankruptcy.

In charitable nonprofit reorganizations, by contrast, the absolute priority rule fails to constrain incumbent fiduciaries because charities have no equity interests for the rule to extinguish. ${ }^{164}$ Charitable debtors are already precluded from retaining equity interests because the charitable nonprofit form prohibits proprietary ownership. ${ }^{165}$ Creditors maintain the right to vote on a nonprofit debtor's proposed reorganization plan; however, if at least one impaired creditor class votes to approve, dissenting creditors cannot use the absolute priority rule as leverage to block confirmation. ${ }^{166}$ Thus, incumbent charitable fiduciaries can obtain confirmation of a contested cram down plan while retaining control over the reorganized debtor.

Creditors have argued that a modified form of the absolute priority rule should apply in charitable nonprofit reorganizations by forcing incumbent fiduciaries to relinquish control over the charity as a condition of confirmation. ${ }^{167}$

163. Bank of Am. Nat'l Trust \& Sav. Ass'n v. 203 N. Lasalle St. P'ship, 526 U.S. 434, 444 (1999). See, e.g., John D. Ayer, Rethinking Absolute Priority After Ahlers, 87 MicH. L. REV. 963, 969 (1989). Wary of "the ability of a few insiders, whether representatives of management or major creditors [affiliated with management], to use the reorganization process to gain an unfair advantage," H.R. Doc. No. 93-137, pt. I, p. 255 (1973), Congress sought to ensure that "creditors [would] be paid before the stockholders [could] retain [equity interests] for any purpose whatever." N. P. R. Co. v. Boyd, 228 U.S. 482, 508 (1913).

164. As one court noted, "the nonprofit status of the Hospital blunts the force of the absolute priority rule, which usually affords creditors leverage to block plans that give value to owners." In re Henry Mayo Newhall Memorial Hosp., 282 B.R. 444, 447 (9th Cir. Bankr. 2002). See generally, Amelia Rawls, Applying the Absolute Priority Rule to Nonprofit Enterprises in Bankruptcy, 118 YALE L.J. 1231 (2009); Pamela Foohey, Chapter 11 Reorganization and the Fair and Equitable Standard: How the Absolute Priority Rule Applies to All Nonprofit Entities, ST. JOHN's LAW REVIEW (forthcoming).

165. 26 U.S.C. $\S 501(\mathrm{c})(3)$ (defining tax-exempt charitable organization as one in which "no part of the net earnings of which inures to the benefit of any private shareholder or individual").

166. A reorganization plan may be confirmed if all classes of impaired creditors vote in favor of the plan. 11 U.S.C. $\S \S 1126,1129$ (a). A claim is impaired if the proposed reorganization plan would disturb legal rights enjoyed by the creditor before the debtor's bankruptcy. 11 U.S.C. $\$ 1124$. If a class of impaired creditors objects, a reorganization plan may be confirmed if at least one class of impaired creditors votes in favor of the plan, which must also meet the requirements of the "cram down" provision. 11 U.S.C. $\S \S 1129(a)(10)$, (b). Debtors sometimes circumvent this requirement by narrowly defining a creditor class to include a single consenting creditor. See, e.g., In re U.S. Truck Co., Inc., 800 F.2d 581 (6 ${ }^{\text {th }}$ Cir. 1986).

167. Cf., In re Henry Mayo Newhall Mem'l Hosp., 282 B.R. 444, 453 (9 $9^{\text {th }}$ Cir. Bankr. 2002) “The Committee [of unsecured creditors] adds that the Hospital's nonprofit status puts creditors in an unusually disadvantaged negotiating position because they are not able to assert the Bankruptcy Code's absolute priority rule to block unacceptable plans that give value to junior interests before paying creditors in full. This is also good argument. The unsecured creditors in the case of a nonprofit entity with no equity 
Courts, however, have consistently rejected that argument. ${ }^{168}$ The statute codifying the absolute priority rule precludes investors from retaining "any property" in the reorganized entity on account of pre-petition equity interests. ${ }^{169}$ Construing this language, courts have narrowly applied the absolute priority rule only to equity interests that confer property rights. As one court explained: "[T]he essence of any equity interest [i]s an ownership or an interest in the organization's profit." ${ }^{170}$ Under this interpretation of the absolute priority rule, an incumbent fiduciary's interest in retaining control over the reorganized debtor is not an ownership interest subject to the absolute priority rule. ${ }^{171}$

To be sure, the public interest would not be served by allowing creditors to dominate the bankruptcy reorganization of insolvent charities. Creditors of an insolvent hospital, for example, may seek to maximize their recovery by proposing a plan that converts the nonprofit hospital to a for-profit business. This result may undermine the public interest because, unlike for-profit hospitals, charitable nonprofit hospitals provide free care to patients who cannot afford to pay. ${ }^{172}$ But, when creditors lack meaningful rights to oppose a debtor's plan of reorganization, the debtor can exploit the opportunity by unjustly enriching insiders and entrenching incumbent fiduciaries. Some scholars have proposed that this problem can be solved by applying a modified form of the absolute priority rule to nonprofit organizations. ${ }^{173}$ Those proposals are laudable.

owners hold the economic interests at the margin of the debtor and are in the same take-it-or-leave dilemma as chapter 13 unsecured creditors, who are not entitled to accept or reject plans. As the marginal class in the case, the unsecured creditors have the greatest incentive to increase the total amount to be paid through the plan - every additional dollar is their money.") (internal citations omitted).

168. In re Indian Nat. Finals Rodeo Inc., 453 B.R. 387, 401 (Bankr. D. Mont. 2011); see also In re Corcoran Hosp. Dist., 233 B.R. 449, 458 (Bankr. E.D. Cal. 1999) ("In the typical Chapter 11 case, [the absolute priority rule] requirement means that equity holders may not retain their interest unless the unsecured class either accepts the plan or is paid in full. In a reorganization . . . of a non-profit corporation under Chapter 11, the requirement must be interpreted somewhat differently. As the debtor has pointed out, there are no holders of equity interests in the debtor here. Thus, what is commonly referred to as the 'absolute priority rule' embodied by $\S 1129(\mathrm{~b})(2)(\mathrm{B})$ does not prevent the debtor here from continuing to operate the hospital."); In re Whittaker Mem'l Hosp. Ass'n, Inc., 149 B.R. 812, 816 (Bankr. E.D. Va. 1993). Courts have reached different results when applying the absolute priority rule to mutual benefit nonprofit organizations which have no charitable purpose. See generally, Amelia Rawls, Applying the Absolute Priority Rule to Nonprofit Enterprises in Bankruptcy, 118 YALE L.J. 1231 (2009) (noting the contrast between application of the absolute priority rule to charitable nonprofit organizations and mutual benefit nonprofit organizations).

169. 11 U.S.C. $\$ 1129(b)(2)(B)(i i)$.

170. In re Indian Nat. Finals Rodeo Inc., 453 B.R. 387, 401 (Bankr. D. Mont. 2011).

171. In re Whittaker Mem'l Hosp. Ass'n, Inc., 149 B.R. 812, 816 (Bankr. E.D. Va. 1993) (“The present group [of incumbent fiduciaries] retaining control over the debtor entity does not give them anything, certainly not a favored position over [the unsecured creditor]. It gives them problems and great anguish ahead. [...] Clearly, there is no distribution to this group and nothing beyond control that passes to it. Being a Virginia nonstock corporation places it in a unique status apart from private enterprise.").

172. See, e.g., Provena Covenant Med. Ctr. v. Dept. of Revenue, 236 Ill.2d 368 (Ill. 2010); Med. Ctr. Hosp. of VT, Inc. v. City of Burlington, 566 A.2d 1352 (Vt. 1989).

173. Amelia Rawls, Applying the Absolute Priority Rule to Nonprofit Enterprises in Bankruptcy, 118 YALE L.J. 1231 (2009); Pamela Foohey, Chapter 11 Reorganization and the Fair and Equitable Standard: How the Absolute Priority Rule Applies to All Nonprofit Entities, 86 St. JoHN's LaW Review 31 (2012). 


\section{Charitable Insolvency and Corporate Governance in Bankruptcy Reorganization}

A related constraint on incumbent corporate fiduciaries is the transfer of ownership and control, what has now been commonplace in for-profit reorganizations. ${ }^{174}$ The transition of ownership helps constrain incumbent fiduciaries because, once in control, new owners have the right to install a new slate of officers and directors. ${ }^{175}$ Empirical research confirms that the change of owner-

174. Cf. Elizabeth Warren, A Theory of Absolute Priority, 1991 ANN. SuRV. AM. L. 9, 12 (1992) ("The [debtor-in-possession] offers, through the plan confirmation, to sell the business to the postreorganization equity owners named in the plan. The new owners may be old creditors who take equity as part of their debt repayment, they may be outsiders who purchase the business, or they may be old equity who purchase the new business. The price, also named in the plan, may be denominated as debt satisfaction, purchase, or contributions, but functionally it is a price for control, ownership, and goingconcern value in the reshaped business."); Elizabeth Warren and Jay L. Westbrook, The Law of Debtors and Creditors at 614 (Aspen 6 ${ }^{\text {th }}$ Ed. 2008) ("It is commonplace for a reorganization to involve the issuance of new stock in the debtor company (common stock, preferred stock, or both), as well as 'warrants' to purchase more stock in the future."); Richard Posner, Economic Analysis of Law at 546 (Aspen Eighth Ed. 2011) ("A typical plan will propose converting the debt of the corporation into stock and other securities to be assigned to the creditors in payment of the corporation's debt to them, so that the creditors will become the corporation's owners."); Robert Rassmussen, The Search for Hercules, 82 WASH. U. L. Q. 1445, 1461 (2005) ("residual claimants tend to be paid in stock").

Incumbent equity interests are typically extinguished in a cram down plan unless creditors view the prior owner's continued participation as necessary to preserve the entity's going concern value after bankruptcy. Thus, the transition of ownership and control is less common in smaller, for-profit, closely held businesses that undergo bankruptcy reorganization because the continued participation of the dominant shareholder/manager is necessary to the continued viability of the reorganized entity. See Lynn M. Lopucki and William C. Whitford, Bargaining Over Equity's Share in the Bankruptcy Reorganization of Large, Publicly Held Companies, 139 U. PA. L. REv. 125, 127 (1990); Douglas G Baird and Thomas H. Jackson, Bargaining After the Fall and the Contours of the Absolute Priority Rule, 55 U. CHI. L. REV. 738,748 (1988). This is not likely the case where the incumbent manager is ineffective or was responsible for bringing about the debtor's insolvency because his continued participation is not likely to ensure the reorganized entity's continued viability.

175. In fact, some bankruptcy scholars argue that agency costs inherent in the Chapter 11 debtor-inpossession system could be reduced by granting residual owners greater control over the reorganization proceeding; under the current system, residual owners often have to wait until the proceeding concludes to exercise control over the reorganized debtor entity. See Robert Rassmussen, The Search for Hercules, 82 WASH. U. L. Q. 1445, 1450-51 (2005) ("The residual owner concept [. . .] is a metric used to assess the structure of governance rights in corporations. The focus on the residual owner stems from agency costs. Such costs arise when ownership and control are separated. The directors and officers are managers, not owners. Hence, their fate is not tied directly to the well-being of the corporation as a whole. They may take actions that increase their security and enhance their own welfare, even though such actions may decrease the overall value of the enterprise. Owners, by contrast, are those who have their own money on the table. Their pocketbooks guide their actions."); Douglas G. Baird \& Thomas H. Jackson, Bargaining After the Fall and the Contours of the Absolute Priority Rule, 55 U. CHI. L. REV. 738, 775 (1988) ("[T] he law of corporate reorganizations should focus on identifying the residual owner, limiting agency problems in representing the residual owner, and making sure that the residual owner has control over the negotiations that the firm must make while it is restructuring."); David Arthur Skeel, Jr., The Nature and Effect of Corporate Voting in Chapter 11 Reorganization Cases, 78 VA. L. REV. 461, 501 (1992) ("Allowing every unsecured creditor to vote would mean that the true residual class of unsecured creditors, as well as nonresidual classes of unsecured creditors, would be free to participate in the vote. Notwithstanding its limitations, however, the benefits of a clear rule outweigh the costs of attempting to determine precisely the firm's residual owners."); Lynn LoPucki, The Myth of the Residual Owner, 82 WASH. U. L. Q. 1341, 1351 (2005) ("The residual owner theory depends on at least a rough congruence between the incentives of the residual owner and the interest of the firm. Theoretically, that congruence could exist not just for a single person as residual owner, but also for a group of people whose interests were essentially the same. Each member of such a group would have the same incentives. They could be expected to act in the same manner, so it would not matter which of them controlled the firm.") (describing, but disagreeing, with the residual owner theory)). 
ship and control in bankruptcy reorganization is highly correlated with attrition among incumbent managers of large for-profit firms. ${ }^{176}$ In charitable nonprofit reorganizations, by contrast, there is no transfer of ownership because (again) the charitable nonprofit form prohibits proprietary ownership interest.

The absence of ownership transfer distorts the reorganization process that, in for-profit cases, is primarily concerned with the sale of the debtor as a going concern. In the for-profit context, new owners have strong financial incentives to maximize the reorganized debtor's going concern value once it emerges from bankruptcy. Blameworthy officers and directors who not displaced during the reorganization process are, therefore, likely to be identified and removed once the bankruptcy proceeding concludes. In the charitable nonprofit context, however, the absence of new ownership tends to leave the charity under the control of incumbent fiduciaries. ${ }^{177} \mathrm{~A}$ charity that enters bankruptcy with dysfunctional leadership is likely to emerge with dysfunctional leadership. At the very least, the Bankruptcy Code should require that a neutral third party examine incumbent charitable fiduciaries before the incumbent retains his or her position in the reorganized debtor entity.

Critics of the residual owner theory argue that large business debtors typically have multiple residual owners with conflicting interests, so the search for a single residual owner is often a futile task. See Lynn LoPucki, The Myth of the Residual Owner, 82 WASH. U. L. Q. 1341, 1343 (2005) ("The typical reorganizing firm has about four investor priority levels that are subordinate to secured and bankruptcy priority creditors. The existence of so many investor priority levels makes it likely that investors at more than one level will share residual owner status."); Thomas H. Jackson \& Robert E. Scott, On the Nature of Bankruptcy: An Essay on Bankruptcy Sharing and the Creditors' Bargain, 75 VA. L. REV. 155, 159 (1989) ("The problem of transferring decision making power from the equity owners [. . .] is compounded by the associated problem that no other class may sufficiently reflect the interests of the claimants taken as a whole. Thus, the objective of the collective is never entirely congruent with the objective of any of the constituent parts."); George G. Triantis \& Ronald J. Daniels, The Role of Debt in Interactive Corporate Governance, 83 CAL. L. REV. 1073, 1100 (1995) ("Even at the best of times, it is difficult to establish a governance process that aligns managerial incentives with the collective interests of all stakeholders. No single investor or class of investors can represent the collective interest of all stakeholders of an insolvent firm.”). Given the difficulty of identifying the residual owner, Professor LoPucki argues that "the bankruptcy system provides the only form of governance practical in the circumstances: a benevolent dictatorship of the board as fiduciary and the bankruptcy judge as referee." Lynn LoPucki, The Myth of the Residual Owner, 82 WASH. U. L. Q. 1341, 1369 (2005).

176. Lynn M. LoPucki \& William C. Whitford, Corporate Governance in the Bankruptcy Reorganization of Large Publicly Held Companies, 141 U. PA. L. REv. 669, 750-51 (1993) ("Our most dramatic empirical finding concerns the fragile tenure of CEOs of large, publicly held companies that reorganize. Tenure is especially fragile for CEOs we have labeled as tainted, virtually all of whom were replaced. Perhaps this should not be surprising. In the cases of insolvent debtors, equity classes seldom retained more than a small minority of the voting shares. A change in management is not an unusual occurrence when there is a shift in control of a large, publicly held company.").

177. When a hospital (or other health care business) files for bankruptcy, however, the bankruptcy court has a statutory duty to appoint an "ombudsman to monitor the quality of patient care and to represent the interests of the patients of the health care business unless the court finds that the appointment of such ombudsman is not necessary for the protection of patients under the specific facts of the case." 11 U.S.C. § 333(a)(1). In theory, the patient care ombudsman may serve as an independent voice in the restructuring process in nonprofit hospital bankruptcy reorganizations where one is appointed. 
Charitable Insolvency and Corporate Governance in Bankruptcy Reorganization

\section{Charitable Exemption from Involuntary Proceedings}

Bankruptcy law has long provided charitable debtors with a special protection unavailable to for-profit business debtors, that is, an exemption from involuntary bankruptcy proceedings. ${ }^{178}$ This protection may harm the public interest in charitable assets by insulating charitable fiduciaries from creditor demands to seek prompt and timely relief in bankruptcy court. Legislative history dating back to 1867 shows that Congress enacted the exemption with the good intention of protecting charities from creditor foreclosure. ${ }^{179}$ When Congress repealed the exemption in $1898,{ }^{180}$ it provoked an impassioned plea on the House floor:

If a church is a corporation and is guilty of an act of insolvency - which it can be under this bill without violating a single precept of the Master-it can be thrown into bankruptcy, and the trustee can take into his possession and sell the bread and wine and the cup and plate which contain them and the sacred book itself [laughter], and leave its members nothing except their hope of salvation in another world. ${ }^{181}$

Congress reinstated the exemption in $1910^{182}$ and the law has remained in place ever since. ${ }^{183}$

178. The exemption's statutory language is somewhat arcane: "An involuntary case may be commenced only under chapter 7 or 11 of this title, and only against a person, except a farmer, family farmer, or a corporation that is not a moneyed, business, or commercial corporation, that may be a debtor under the chapter under which such case is commenced." 11 U.S.C. § 303(a).

179. The Bankruptcy Act of 1867 provided a blanket exemption for nonprofit organizations, excluding them from all provisions of the bankruptcy laws: "[T]he provisions of this act shall apply to all moneyed business or commercial corporations and joint stock companies." Act of Mar. 2, 1867, ch. 176, § 37,14 Stat. 517,535 . Thus, by implication, the involuntary provision did not apply to non-commercial corporations including nonprofit charities. Debate on the Senate floor reveals the careful and deliberate wording of the statute, which used the term "commercial" rather than "business" because the latter could be "construed to include all corporations to carry on any kind of business, even the business of distributing charities or the business of employing teachers in schools, or of conducting religious exercises." Cong. Globe, $39^{\text {th }}$ Cong., 2d Sess. 1002 (1867). See Henry Hansmann, The Evolving Law of Nonprofit Organizations: Do Current Trends Make Good Policy?, 39 CASE W. RES. 807, 810 n.6 (1989) ("The Bankruptcy Act of 1867 exempted nonprofits from both voluntary and involuntary bankruptcy."). Cong. Globe, $39^{\text {th }}$ Cong., 2d Sess. 987 (1867). See also Michael Sovern, Section 4 of the Bankruptcy Act: The Excluded Corporations, 42 MinN. L. REV. 171, 172 (1957).

180. Bankruptcy Act of 1898 §4(b).

181. 31 Cong. Rec. 1939 (1898).

182. The 1910 amendments reinstated the exemption provision from the Bankruptcy Act of 1867, which limited involuntary proceedings to "any moneyed business, or commercial corporation." Act of June 25,1910 , ch. $412, \S 4,36$ Stat. 838, 839 ("Any person, except a municipal, railroad, insurance, or banking corporation, shall be entitled to the benefits of this Act as a voluntary bankrupt. [. . .] [A]ny unincorporated company, and any moneyed business, or commercial corporation . . . may be judged an involuntary bankrupt upon default."); see also Henry Hansmann, The Evolving Law of Nonprofit Organizations: Do Current Trends Make Good Policy?, 39 CASE W. RES. 807, 810 n.6 (1989) ("the purpose of the amendment was to confine the exemption to involuntary bankruptcy").

183. 11 U.S.C. § 303(a) (“An involuntary case may be commenced ... only against a . . . corporation that is not a moneyed business, or commercial corporation. . . see also In re Mem'l Med. Ctr., Inc., 337 
Although intended by Congress to protect charities, the exemption, in practice, enables charitable fiduciaries to postpone seeking bankruptcy reorganization to the point when financial rehabilitation is no longer feasible. Bankruptcy relief is most effective when sought early enough to benefit from the "automatic stay" that applies upon filing of a bankruptcy petition. ${ }^{184}$ The automatic stay helps preserve the debtor as a going concern by preventing creditors from pursuing individual remedies against the debtor outside the bankruptcy process. ${ }^{185}$ Piecemeal collection impairs the debtor's ability to operate as a going concern and, consequently, undermines the overall value of the bankruptcy estate. ${ }^{186}$ Thus, bankruptcy reorganization is most effective when invoked before individual creditors have had a chance to deplete the debtor's assets.

The benefits from a prompt pursuit of bankruptcy relief do not always flow to the debtor's incumbent officers and directors, who often delay seeking bankruptcy protection until the debtor has become irrevocably insolvent. ${ }^{187}$ Scholars attribute the pattern of delay to numerous behavioral factors, including the tendency of corporate fiduciaries to: (1) exhibit "overconfidence bias" in their ability to resolve the company's financial problems; (2) engage in "pathdependent" decision-making, wherein managers remain irrationally committed to their own prior decisions even when confronted with contrary information; and (3) cut corners by avoiding the effort involved in reconsidering prior deci-

B.R. 388, 390 (Bankr. D.N.M. 2005) (“Courts interpreting this section consistently conclude that nonprofit organizations are not subject to involuntary proceedings."). Under Chapter 11, the bankruptcy court may convert a reorganization case to a Chapter 7 liquidation proceeding when in the creditors' best interest, but in the case of charitable nonprofit debtors, such conversion requires consent from the debtor. 11 U.S.C. $\S 1112(\mathrm{c})$.

One scholar has suggested that the "Bankruptcy Act of 1947" repealed the nonprofit exemption from involuntary proceedings. See Nina Crimm, Evolutionary Forces: Changes in For-Profit and Not-ForProfit Health Care Delivery Structures: A Regeneration of Tax Exemption Standards, 37 B.C. L. REV. 1, 7 n. 19 (1995) ("The Bankruptcy Act of 1867 exempted not-for-profit organizations from voluntary and involuntary bankruptcy, and as late as 1947 not-for-profit institutions were exempt from involuntary bankruptcy. Bankruptcy Act of March 2, 1867, ch. 176, 14 Stat. 517 (1867), amended by Act of June 25, 1910, ch. 412, § 4, 36 Stat. 838, 839 (1910), repealed by Bankruptcy Act of 1947, ch. 391, 61 Stat. 213 (1947)."). I could not locate legislation from 1947 repealing the exemption and the author's citations to the public law do not correspond to legislation repealing the exemption. 61 Stat. 213 (1947) (regarding qualifications of part-time bankruptcy referees); 61 Stat. 652 (1947) (regarding copyright law).

184. 11 U.S.C. $\$ 362(a)$.

185. "The automatic stay is one of the fundamental debtor protections provided by the bankruptcy laws. It gives the debtor a breathing spell from his creditors. It stops all collection efforts, all harassment, and all foreclosure actions. It permits the debtor to attempt a repayment or reorganization plan, or simply to be relieved of the financial pressures that drove him into bankruptcy. The automatic stay also provides creditor protection. Without it, certain creditors would be able to pursue their own remedies against the debtor's property. Those who acted first would obtain payment of the claims in preference to and to the detriment of other creditors. Bankruptcy is designed to provide an orderly liquidation procedure under which all creditors are treated equally. A race of diligence by creditors for the debtor's assets prevents that." H.R. REP. 95-595, § 362, 1978 U.S.C.C.A.N. 5963, 6096-97

186. Id.

187. A. Mechele Dickerson, A Behavioral Approach to Analyzing Corporate Failures, 38 WAKE FOREST L. REV. 1, 4-7 (2003); see also Elizabeth Warren and Jay L. Westbrook, The Law of Debtors and Creditors at 367 (Aspen 6th Ed. 2008) ("There is a consensus that far too often companies do not file [for bankruptcy] until it is too late to save them and most of their value has been dissipated."). 
Charitable Insolvency and Corporate Governance in Bankruptcy Reorganization

sions initially thought to be final. ${ }^{188}$ The Bankruptcy Code exacerbates the problem of delay by failing to impose sanctions on debtors who are "dead on arrival" at the bankruptcy courthouse. ${ }^{189}$ Scholars have yet to quantify incidence of "dead on arrival" bankruptcy cases attributable to debtor delay, but the fact that most business bankruptcy cases result in liquidation rather than reorganization suggests that delay is a nontrivial problem. ${ }^{190}$

In for-profit cases, the right of creditors to bring an involuntary proceeding imposes an important constraint on debtor delay. Formal involuntary proceedings are rarely initiated by creditors because they involve substantial costs and risks not present in voluntary bankruptcy cases,${ }^{191}$ but the availability of involuntary proceedings provides creditors with leverage to pressure insolvent debtors into filing a voluntary case. ${ }^{192}$ This leverage can be potent because involuntary proceedings typically result in termination of the debtor as a going concern, the worst possible outcome for the debtor's incumbent fiduciaries. As put by one Congressman: "Voluntary bankruptcy is the means of the redemption of the unsuccessful and fallen debtor. Involuntary bankruptcy is a weapon in the hands of the creditor to press collections of debt harshly, to intimidate, and to destroy." 193

Although charities tend to avoid debt financing, for the reasons explained above, charities do have general liabilities and creditors (e.g., landlords, contractual counterparties, pensioners, employees, suppliers, etc.). Thus, by exempting charitable debtors from involuntary proceedings, the Bankruptcy Code deprives creditors of an important source of leverage when bargaining with an insolvent charity. This, in turn, enables blameworthy fiduciaries to delay seeking bankruptcy and the heightened transparency that would accompany a formal reorganization proceeding. Given the broader problems of charitable accountability and lack of charitable oversight outside of bankruptcy, there are

188. See A. Mechele Dickerson, A Behavioral Approach to Analyzing Corporate Failures, 38 WAKE FOREST L. REV. 1, 4-7 (2003).

189. Id. at 20-21.

190. See, e.g., Elizabeth Warren And Jay L. Westbrook, The LAw of DebTORS AND CREDITORS at 364 (Aspen 6th Ed. 2008) (in 2007, two-thirds of business bankruptcy filings were liquidation proceedings under Chapter 7); Elizabeth Warren, Federal Bankruptcy, 1992 CORNELL L. REV. 1093, 1097 (noting that a third of Chapter 11 proceedings result in liquidation).

191. See, e.g., Elizabeth Warren AND Jay L. WeStbrook, The LAW of DeBtors AND CREDITORS at 368 (Aspen $6^{\text {th }}$ Ed. 2008) (noting the small, but perhaps growing, number of involuntary proceedings); see also Susan Block-Lieb, Why Creditors File So Few Involuntary Petitions and Why the Number Is Not Too Small, 57 BROOK. L. REV. 803 (1991). For example, if a group of creditors initiates an involuntary proceeding and the bankruptcy court finds their claim of insolvency lacks merit, creditors bear the debtor's costs associated with defending the proceeding. 11 U.S.C. $\S$ 303(i).

192. See, e.g., RichARD PoSNER, ECONOMIC ANALYSIS OF LAW at 546 n.5 (Aspen 8th Ed. 2011) ("Although the shareholders take the initiative in proposing the plan of reorganization, rarely do they file for protection under Chapter 11 (the reorganization provision) unless creditors are about to force the company into bankruptcy.").

193. 31 Cong. Rec. 1908 (statement of Congressman Elijah Lewis). See In re Gibraltor Amusements, 291 F.2d 22, 27 (2d Cir. 1961) (J. Friendly, dissenting). 
good reasons to expect charitable fiduciaries to be equally (if not more) prone to delay as their for-profit counterparts. These problems counsel in favor of repealing the exemption and subjecting insolvent charities to involuntary proceedings in the same manner as for-profit debtors.

Admittedly, repealing the charitable exemption from involuntary proceedings may only play a small role in constraining incumbent fiduciaries because creditors infrequently resort to involuntary proceedings. This suggests that repeal of the exemption would not cause an onslaught of foreclosures in the charitable nonprofit sector. Even if creditors remain reticent to use the threat of an involuntary proceeding as leverage to force a charitable debtor into bankruptcy, repeal of the exemption might send a symbolic message to charitable fiduciaries and encourage the prompt pursuit of bankruptcy relief at the earliest sign of insolvency.

\section{IDEAS FOR REFORM}

This Part offers nascent ideas for policy reform to help insolvent charities identify and remove incompetent, negligent, or otherwise blameworthy managers whose conduct contributed to the charity's financial distress. While a more comprehensive analysis and proposal of policy reform will be the topic of another article, this Part proposes ideas that lawmakers might consider in fashioning a solution.

One possibility for reform would designate the bankruptcy reorganization process as a mandatory point of governmental intervention for financially distressed charities to achieve two important objectives: (1) identification and removal of blameworthy incumbent fiduciaries from insolvent charities seeking to reorganize and (2) deterrence of blameworthy conduct by incumbent fiduciaries of solvent charities. To accomplish both objectives, the Bankruptcy Code should be amended to provide for the presumptive appointment of bankruptcy examiners in large charitable bankruptcies. By presumptively appointing a bankruptcy examiner, the law would subject the failing charity's management and financial affairs to exacting scrutiny. In cases where the bankruptcy examiner identifies one or more charitable fiduciaries who breached their legal obligations to the charity, the bankruptcy court should deny confirmation of the charity's reorganization plan until the offending individuals agree to resign, thus protecting the charity from further harm once it emerges as a reorganized entity. To prevent charitable fiduciaries from avoiding the scrutiny of an examiner by postponing or refusing to invoke bankruptcy relief, Congress should also repeal the charitable exemption from involuntary proceedings. 
Charitable Insolvency and Corporate Governance in Bankruptcy Reorganization

\section{A. Bankruptcy as a Point of Governmental Intervention}

The bankruptcy process has always served as a point of governmental intervention between insolvent debtors and the range of stakeholders adversely affected by financial default. A rich literature of bankruptcy scholarship has explored whether the Bankruptcy Code and bankruptcy courts perform an efficient gatekeeping function by identifying which insolvent firms are viable in the long run (good candidates for reorganization) and which firms lack any reasonable prospects for financial rehabilitation (good candidates for liquidation). ${ }^{194}$ While it is difficult to devise a system that performs this function perfectly, ${ }^{195}$ empirical evidence shows that creditors and courts are quite efficient at sorting out hopelessly insolvent cases at the earliest stages of the reorganization proceeding. ${ }^{196}$ Debtors that survive the reorganization proceeding's initial sorting process are far more likely to proceed to plan confirmation and emerge from bankruptcy as a going concern. ${ }^{197}$

Bankruptcy can also serve a gatekeeping function by providing neutral third-party scrutiny of the debtor's incumbent managers. In the for-profit bankruptcy context, for example, recent scholarship has advocated heightened supervision and scrutiny of incumbent fiduciaries to alleviate the corporate governance problems created by Chapter 11's debtor-in-possession provisions. ${ }^{198}$ If greater external supervision is necessary in the for-profit bankruptcy contextwherein shareholders and creditors provide accountability that helps to con-

194. See, e.g., Michelle White, Corporate Bankruptcy as a Filtering Device: Chapter 11 Reorganizations and Out-of-Court Restructurings, 10 J. L. ECON. \& ORG. 268, 269 (1994) (arguing that, "from an efficiency standpoint," the goal of bankruptcy law is to shut down firms that "should liquidate since they are economically inefficient" and reorganize firms "that should remain in operation since they are economically efficient"); Michelle J. White, Does Chapter 11 Save Economically Inefficient Firms?, 72 WASH. U. L.Q. 1319, 1319 (1994); Yaad Rotem, What is Missing in Corporate Bankruptcy Theories? Revisiting the Efficiency Rationale, 39 ISR. L. REV. 180, 183 (2006) ("[A]n optimal bankruptcy procedure should attempt to screen and discern financially-distressed-but-economically-viable firms from financially-and-economically-distressed firms. While the former need continue to operate as a going concern--and perhaps undergo a restructuring of its capital for that purpose--the latter should be shut down and its assets should be redeployed elsewhere in the economy"); Jeremy I. Bulow \& John B. Shoven, The Bankruptcy Decision, 9 BELl J. ECON. 437 (1978); Robert M. Mooradian, The Effect of Bankruptcy Protection on Investment: Chapter 11 as a Screening Device, 49 J. FIN. 1403 (1994).

195. See Michelle White, Corporate Bankruptcy as a Filtering Device: Chapter 11 Reorganizations and Out-of-Court Restructurings, 10 J. L. ECON. \& ORG. 268, 269 (1994) ("The dilemma in bankruptcy is that, given imperfect information, it may be impossible to save all efficient failing firms and also shut down all inefficient failing firms. Any policy designed to shut down inefficient failing firms will also shut down some efficient but failing firms. And any policy designed to save efficient but failing firms will also save some inefficient firms.").

196. Elizabeth Warren and Jay Westbrook, The Success of Chapter 11: A Challenge to the Critics, 107 MiCH. L. REV. 603, 620-23 (2009)

197. Id. at 623. ("Success is an elusive concept, but these data show that when Chapter 11 performed its sorting function, plan-confirmation rates were quite high.").

198. Kelli A. Alces, Enforcing Corporate Fiduciary Duties in Bankruptcy, 56 KAN. L. REV. 83 (2007) (recommending routine appointment of bankruptcy trustee); Michelle M. Harner, The Search for an Unbiased Fiduciary in Corporate Reorganizations, 86 NOTRE DAME L. ReV. 469 (2011) (recommending appointment of a case facilitator). 
strain agency costs - then a fortiori, neutral third-party oversight is critically important in the charitable nonprofit context, where insiders and fiduciaries are subject to minimal (if any) accountability. In recent amendments to the Bankruptcy Code, Congress implicitly recognized the need for greater supervision in charitable bankruptcy cases by clarifying that state attorneys general have standing to intervene, but attorneys general have always had this right and, for reasons explained above, state attorney general oversight is notoriously ineffective. ${ }^{199}$ Further reform is necessary to constrain corporate governance in charitable reorganization cases to protect charitable assets from waste and abuse by incompetent and self-dealing incumbent fiduciaries.

As explained in the next section, one option for reform would involve the presumptive appointment of a neutral third-party examiner to ascertain the cause of the charity's financial distress and determine whether governance problems contributed to the condition of insolvency. This form of governmental intervention could be accomplished effectively without disturbing the broader goals of bankruptcy law ${ }^{200}$ or impairing existing legal rights of bankruptcy stakeholders. ${ }^{201}$

199. The Bankruptcy Abuse Prevention and Consumer Protection Act of 2005 provides, "The parties who may appear and be heard in a proceeding under this section include the attorney general of the State in which the debtor is incorporated, was formed, or does business." 119 Stat. 196, §1221(d). This provision did not amend any codified text of the Bankruptcy Code, but clarified that the state attorney general may intervene in a bankruptcy proceeding involving a charitable nonprofit organization. State attorneys general have long had this power, so the amendment had little substantive effect. See, e.g., In re Winsted Mem'l Hosp., 249 B.R. 588 (Bankr. D. Conn. 2000) (permitting attorney general intervention); Hunter v. St. Vincent Med. Ctr. (In re Parkview Hosp.), 211 B.R. 619 (Bankr. N.D. OH. 1997) (permitting attorney general intervention).

200. The twin aims of bankruptcy law are to preserve and distribute the debtor's assets to unpaid creditors in a fair and orderly fashion, and where reorganization is possible, provide a fresh start for the reorganized debtor. See, e.g., Grogan v. Garner, 498 U.S. 279, 286 (1991) (“[A] central purpose of the [Bankruptcy] Code is to provide a procedure by which certain insolvent debtors can reorder their affairs, make peace with their creditors, and enjoy a new opportunity in life and a clear field for future effort, unhampered by the pressure and discouragement of preexisting debt.") (internal quotation marks omitted); Begier v. IRS, 496 U.S. 53, 58 (1990) ("Equality of distribution among creditors is a central policy of the Bankruptcy Code.”); Elizabeth Warren, Bankruptcy Policy, 54 U. CHI. L. REV. 775, 782, 785 (1987) ("Bankruptcy law aims first to conserve and divide an estate that cannot meet all its obligations, and second to terminate the rights of unpaid creditors.").

201. Professor Douglas Baird argues that bankruptcy law should refrain from creating priorities or rights that do not exist outside of bankruptcy because doing so would encourage systemically harmful forum shopping between bankruptcy and state law debt collection remedies. According to Baird, if special bankruptcy priorities for non-creditor stakeholders impair creditor rights, then creditors would have an incentive to avoid the bankruptcy system altogether by pursuing collection remedies in state court, thereby exacerbating the collective action problem among creditors that bankruptcy law attempts to resolve. Douglas G. Baird, Loss Distribution, Forum Shopping and Bankruptcy: A Reply to Warren, 54 U. CHI. L. REV. 815, 822, 826 (1987) (describing the forum shopping paradigm); Douglas G. Baird, A World Without Bankruptcy, 50 Law \& Contemp. Probs. 173, 183-84 (1987). But see Elizabeth Warren, Bankruptcy Policy, 54 U. CHI. L. REV. 775, 788 (1987) (arguing that bankruptcy law should (and does) protect the interests of stakeholders such as "[t]he older employee, the regular customer, the dependent supplier, and the local community" of the debtor because of the "deep[] social implications of business failure in a highly integrated society"); Nathalie D. Martin, Noneconomic Interests in Bankruptcy: Standing on the Outside Looking In, 59 Оніо ST. L.J. 429 (1998) (arguing that bankruptcy law should account for nonpecuniary interests, such as community stakeholders reliant upon the debtor). 
Charitable Insolvency and Corporate Governance in Bankruptcy Reorganization

\section{B. Presumptive Appointment of Bankruptcy Examiner}

To protect the public interest, the Bankruptcy Code could provide for the presumptive appointment of a bankruptcy examiner in all reorganization cases involving substantial charitable assets. Bankruptcy examiners are "private individuals appointed by the United States Trustee at the direction of a bankruptcy court" ${ }^{202}$ who are charged with investigating "any allegations of fraud, dishonesty, incompetence, misconduct, mismanagement, or irregularity of management of the affairs of the debtor of or by current or former management of the debtor ...." ${ }^{203}$ Examiners perform court-directed investigations and produce a report that is presumptively available to the public. ${ }^{204}$ Examiners are "supposed to expose and explain things that others cannot or will not in ways the system deems reliable and efficient." ${ }^{205}$ According to bankruptcy participants, most examiners are attorneys or forensic accountants who are typically "neutral, professional and competent."206

The Bankruptcy Code currently provides that "on request of a party in interest ... the court shall order the appointment of an examiner to conduct such an investigation of the debtor as is appropriate ... if . . . the debtor's fixed, liquidated, unsecured debts, other than debts for goods, services, or taxes, or owing to an insider, exceed $\$ 5$ million." ${ }^{207}$ Congress intended the bankruptcy examiner provision to provide "special protection for the large cases having great public interest . . . to determine fraud or wrongdoing on the part of present management." 208 Although the statute appears to contain mandatory language (i.e., "the court shall order the appointment of an examiner" in cases involving debts exceeding \$5 million), many bankruptcy courts have construed the provision as discretionary rather than mandatory. ${ }^{209}$ Empirical research shows that examiners are underutilized, as parties requested the appointment of an examiner in only $15.1 \%$ of sampled cases and bankruptcy courts granted requests in only $6.7 \%$ of cases. ${ }^{210}$

Professor Jonathan Lipson has proposed a theoretical model, based on a recent empirical study of examiner appointments, to identify cases in which

202. Jonathan Lipson, Understanding Failure: Examiners and the Bankruptcy Reorganization of Large Public Companies, 84 AM. BANKR. L.J. 1, 2 (2010).

203. 11 U.S.C. $\S 1104(c)$.

204. Jonathan Lipson, Understanding Failure: Examiners and the Bankruptcy Reorganization of Large Public Companies, 84 AM. BANKR. L.J. 1, 49 (2010).

205. Id. at 47 .

206. Id.

207. 11 U.S.C. $\S 1104(c)(2)$

208. 124 Cong. Rec. S17403-34 (daily ed. Oct. 6, 1978); See generally, Jonathan Lipson, Understanding Failure: Examiners and the Bankruptcy Reorganization of Large Public Companies, 84 AM. BANKR. L.J. 1 (2010).

209. Jonathan Lipson, Understanding Failure: Examiners and the Bankruptcy Reorganization of Large Public Companies, 84 AM. BANKR. L.J. 1, 14 (2010).

210. Id. at 27. 
such appointments are most appropriate: (1) cases in which a "conventional cost-benefit calculus shows they have net positive value: the projected recoveries to stakeholders (creditors, in particular) from appointing an examiner likely exceed the examiner's projected costs;" (2) cases in which "there is some conflict of interest that prevents the system from working in a reasonably fair and efficient way"; and (3) cases that implicate the public interest. ${ }^{211}$ Professor Lipson argues that examiners should be presumptively appointed in large bankruptcy reorganizations because, in part, it would force incumbent parties to articulate specific and concrete reasons why an examiner would not be necessary. ${ }^{212}$

Under Professor Lipson's model, there are often compelling reasons to appoint a bankruptcy examiner in large charitable reorganizations. As explained above, charitable nonprofit reorganizations present inherent conflicts of interest that prevent the bankruptcy system from working fairly and efficiently. The principal stakeholders - charitable beneficiaries and the public at large-are typically not represented in charitable nonprofit reorganizations (aside from representation by the charity's own fiduciaries). This leaves charitable officers and directors, who have strong personal interests in preserving their own control over the reorganized charity, in a position to exert influence over the bankruptcy proceeding with little or no external accountability. Parties that typically constrain incumbent fiduciaries in the for-profit context (new owners and creditors) are either absent or lack sufficient leverage in the charitable nonprofit context. The examiner would constrain the influence of incumbent fiduciaries by scrutinizing their conduct and recommending a change of leadership where appropriate.

Professor Lipson proposes expanding the use of examiners by presuming such appointments to be in the best interests of creditors, equity security holders, and the reorganization process if: (1) "there are allegations of fraud, dishonesty, incompetence, misconduct, mismanagement or irregularity in the management of the affairs of the debtor of or by current or former management of the debtor;" (2) the debtor is a publicly traded company with $\$ 100$ million or more assets; or (3) "an examiner would otherwise facilitate the reorganization process, considering the costs and benefits of an examiner." ${ }^{213}$ Professor Lipson's proposal would still limit examiner appointments to cases wherein a party affirmatively requests an appointment by the bankruptcy court. ${ }^{214}$

To protect the public interest in charitable assets, the Bankruptcy Code's examiner provision might go a step further than Professor Lipson's proposal in reorganization proceedings involving large sums of charitable assets. Specifi- 
Charitable Insolvency and Corporate Governance in Bankruptcy Reorganization

cally, the Bankruptcy Code could be amended to provide for the presumptive appointment of a bankruptcy examiner in all large charitable nonprofit reorganizations involving charitable assets. By using the current examiner statute as a guide, the threshold for imposing the presumption would perhaps be charitable assets exceeding \$5 million. ${ }^{215}$ Since the public at large and charitable beneficiaries are generally not represented in charitable bankruptcy reorganizations, examiners would be presumptively appointed by the court even absent a request by parties to the proceeding or allegations of wrongdoing. By adopting this presumption, the charity would be forced to provide an accounting to the public; either the examiner will prepare a report identifying the primary causes of insolvency or the charity will provide convincing reasons to the bankruptcy court of why an examiner need not be appointed. Incumbent charitable fiduciaries could rebut the presumption by demonstrating that the charity's financial distress is not attributable to a breach of fiduciary duty.

When an examiner uncovers a breach of fiduciary duty by incumbent charitable officers and directors, the bankruptcy court could consider whether the charity's retention of breaching fiduciaries would undermine its ability to rehabilitate itself. If retention of incumbents would thwart the charity's financial recovery, then the bankruptcy court could reject the proposed plan of reorganization. To obtain plan confirmation, proponents must establish that "[c]onfirmation of the plan is not likely to be followed by the liquidation, or the need for further financial reorganization, of the debtor or any successor to the debtor under the plan, unless such liquidation or reorganization is proposed in the plan." 216 Thus, if retention of the breaching fiduciaries would compromise the charity's ability to emerge from reorganization on firm financial footing, then the bankruptcy court has a statutory obligation to deny plan confirmation. This would hasten the removal of breaching fiduciaries and enable the charity to achieve a fresh start following reorganization. ${ }^{217}$ In determining whether a breaching fiduciary is likely to compromise the charity's reorganization, bankruptcy courts would consider whether the individuals engaged in improper selfdealing transactions, incompetence, or negligent oversight.

Public scrutiny performed by a bankruptcy examiner may also help regulate corporate governance among charitable fiduciaries by deterring misconduct that causes financial distress. Professor Lipson argues that examiners serve an important function by publicly shaming blameworthy incumbents which, in turn,

215. The bankruptcy examiner statute contemplates the appointment of examiners in cases involving debts exceeding \$5 million. 11 U.S.C. § 1104(c)(2).

216. 11 U.S.C. $\S 1129(a)(11)$.

217. In an analogous setting, the Restatement (Third) of Trusts outlines several possible remedies for breach of trust such as ordering an accounting, restitution, personal liability, reduction of compensation, recovery of improper distributions, and removal. Restatement (Third) of Trusts $\S 95 \mathrm{cmts}$. b-c (2012). 
deters corporate fiduciaries from engaging in negligence or misconduct. ${ }^{218}$ As Professor Lipson explains:

We tend to forget today that bankruptcy was once a crime, a stigmatized act. While recent amendments to the Bankruptcy Code have sought to re-stigmatize consumer bankruptcy, we largely exempt business bankruptcy from this normative judgment. The managers who lead their firms to failure have little to fear. If their compensation packages are properly designed they will collect a healthy (albeit smaller-thananticipated) severance and go on about their business. There is little cost for error in the executive suite because, except in extraordinary-i.e., criminal-cases, managers will usually walk away far better off than their employees and, in many cases, creditors. They will not be forced to explain what they did wrong or, by inference, be deterred from making similar mistakes in the future. There is no shame in corporate failure in part because there is no exposure. We neither learn from failure nor, through the trial of investigation, deter it.

Examiners could help to fix this. Used more frequently (and judiciously), examiners would not only explain bad practices that led to failure but also send a signal to future managers: if you fail, you will likely be examined, and the examination may lead to causes of action against you. At minimum, your errors would likely be subject to greater scrutiny than is currently the case. ${ }^{219}$

If bankruptcy examiners are able to deter wrongful conduct by corporate fiduciaries before the debtor reaches the point of insolvency, then bankruptcy law could play an important role in improving charitable governance more broadly. Many charitable fiduciaries - particularly directors and trustees on charitable boards - cherish their positions for reasons of social and professional prestige; the shame associated with removal for cause in bankruptcy might encourage better governance and oversight as a matter of course. This could help solve some of the charitable accountability problems outside of bankruptcy that have thus far eluded a satisfactory solution.

One potential drawback associated with heightened scrutiny for charitable fiduciaries is that the possibility of removal "for cause" might chill incentives for volunteers to serve on charitable boards as trustees or directors. ${ }^{220}$ (Height-

218. Jonathan Lipson, Understanding Failure: Examiners and the Bankruptcy Reorganization of Large Public Companies, 84 AM. BANKR. L.J. 1, 64 (2010).

219. Id. at 65 .

220. Cf., Thomas Lee Hazen and Lisa Love Hazen, Punctilios and Nonprofit Corporate Governance- 
Charitable Insolvency and Corporate Governance in Bankruptcy Reorganization

ened scrutiny presents less of a concern for charitable officers because they are compensated for their services.) To avoid deterring well-intentioned volunteers from serving on charitable boards, bankruptcy courts should approach the need to remove directors and trustees with deference to the volunteer nature of their service. Bankruptcy courts could do so by emphasizing, where appropriate, that although a fiduciary should be removed for breach of fiduciary duty, the individual acted in good faith. "Good faith" language would not be appropriate in cases involving gross negligence or breach of the duty of loyalty. The possibility of receiving "good faith" language from the bankruptcy court might be enough to placate well-intentioned volunteer trustees and avoid en mass resignations at the first sign of financial distress.

Another potential drawback would be the cost of bankruptcy examiner appointments. Although this Article proposes reform designed to avoid the cost of creating a new government agency to review charitable insolvencies, a system in which bankruptcy examiners are presumptively appointed would impose new costs arising from the examiner's fee. The bankruptcy estate would typically pay this for this cost. ${ }^{221}$ However, since the primary purpose of this proposal is to protect the public interest in charitable assets, Congress (or states) might consider reimbursing charities for the cost of bankruptcy examiner appointments from the public fisc. Alternatively, in cases where an examiner uncovers a breach of fiduciary duty, bankruptcy courts might consider imposing a surcharge on individuals responsible for causing the charity's financial distress. $^{222}$

Empirical research on the cost of bankruptcy examiners reveals that, in some cases, examiner fees can be substantial. ${ }^{223}$ The same research, however, also shows that most bankruptcy examiners have historically been appointed in very large bankruptcy cases involving net assets of $\$ 100$ million or more. ${ }^{224}$ Empirical research has yet to provide insight into the cost of bankruptcy examiners in smaller cases, which is perhaps the more relevant inquiry because most

-A Comprehensive Look at Nonprofit Directors' Fiduciary Duties, 14 U. PA. J. BUS. L. 347, 414 (2012) ("Qualified potential candidates would be less likely to serve on nonprofit boards if the law did not limit liability of nonprofit directors.").

221. 11 U.S.C. $\S 330$.

222. In cases involving uncompensated volunteer directors or trustees who breached their fiduciary duty, a surcharge would be permissible where "the harm was caused by willful or criminal misconduct, gross negligence, reckless misconduct, or a conscious, flagrant indifference to the rights or safety of the individual harmed by the volunteer." 42 U.S.C. $\S 14503(\mathrm{a})(3)$. Otherwise, imposing a surcharge would be foreclosed by state and federal laws protecting uncompensated volunteers from financial liability. See Thomas Lee Hazen \& Lisa Love Hazen, Punctilios and Nonprofit Corporate Governance-A Comprehensive Look at Nonprofit Directors' Fiduciary Duties, 14 U. PA. J. BUS. L. 347, 413 (2012).

223 See, e.g., Jonathan Lipson, Understanding Failure: Examiners and the Bankruptcy Reorganization of Large Public Companies, 84 AM. BANKR. L.J. 1, 53 (2010) (noting that the Enron examiners cost $\$ 100$ million).

224 Jonathan Lipson, Understanding Failure: Examiners and the Bankruptcy Reorganization of Large Public Companies, 84 AM. BANKR. L.J. 1, 46 (2010). 
charities have less than $\$ 100$ million in assets. To contain costs, bankruptcy courts should narrowly tailor the examiner's scope of work to reflect the size, complexity, and individual situation of each case and closely scrutinize fees billed to the bankruptcy estate. Further, Congress should consider capping the examiner's fee at $1 \%$ of net assets. In a case involving $\$ 5$ million in net assets, this would provide up to $\$ 50,000$ to pay the examiner's fees. An examiner charging \$250 per hour would be compensated for up to 200 hours of work, a sufficient amount of time to investigate and report on the financial affairs of a relatively small organization. A rough cost-benefit analysis suggests that it would be worth spending $1 \%$ of the charity's net assets to protect the other $99 \%$.

As an additional measure, the United States Department of Justice could apply heightened scrutiny in charitable nonprofit reorganizations through greater participation by United States Trustee. The United States Trustee is a division within the Department of Justice with statutory powers to monitor, oversee, and intervene in all bankruptcy proceedings to protect creditors as well as the public interest. ${ }^{225}$ Courts have explicitly construed the United States Trustee's duty as including an obligation to protect the public interest ${ }^{226}$ and the United States Trustee has occasionally intervened in cases involving charitable

225. 28 U.S.C. $\S \S 581-586 ; 11$ U.S.C. $\S \S 1104,1106$. According to the United States Trustee:

The mission of the United States Trustee Program is to promote the integrity and efficiency of the bankruptcy system for the benefit of all stakeholders - debtors, creditors, and the public. By statute, the Program has standing to participate in every bankruptcy case within its jurisdiction. The Program oversees the administration of all bankruptcy cases filed by individual and business debtors in every federal judicial district except for those in Alabama and North Carolina. The U.S. Trustee's specific duties in a case depend on the chapter under which a debtor files a bankruptcy petition and the facts of the case. The Program has a headquarters office in Washington, D.C., led by a Director; 21 regions managed by U.S. Trustees; and 95 field offices supervised by Assistant U.S. Trustees. At the conclusion of FY 2011, the Program had 1,239 employees, consisting of attorneys, financial analysts, paralegals, and support staff. More than 90 percent of the Program's employees are located in its field offices. The Program is funded through user fees paid by bankruptcy debtors. All revenues are deposited into the United States Trustee System Fund and remain available for expenditure, as specified in appropriations acts. Deposits to the United States Trustee System Fund consist of filing fees, chapter 11 quarterly fees, and interest on investments and other miscellaneous revenue. In FY 2011, the Program's total funding level was \$222.4 million, consisting of \$218.8 million in appropriations and \$3.6 million in carryover funding from the previous fiscal year.

United States Trustee Program Annual Report: Fiscal Year 2011, U.S. Dept. of Justice, http://www.justice.gov/ust/eo/public_affairs/annualreport/docs/ar2011.pdf.

226. See In re Columbia Gas Sys., Inc., 33 F.3d at 296 (noting that Congress has stated that U.S. Trustees are responsible for protecting the public interest); In re Clark, 927 F.2d 793, 795 (4th Cir. 1991) (labeling the U.S. Trustee a "watchdog" who must see that the bankruptcy laws are enforced); In re Plaza de Diego Shopping Ctr., Inc., 911 F.2d 820, 824 (1st Cir. 1990) (noting the U.S. Trustee's statutory responsibility to represent and to protect the public); In re Revco D.S., Inc., 898 F.2d 498, 500 (6th Cir. 1990) (opining that the U.S. Trustees protect the public interest just as watchdogs guard the interests of those for whom they watch). 
Charitable Insolvency and Corporate Governance in Bankruptcy Reorganization

debtors. ${ }^{227}$ The United States Trustee, which is often responsible for appointing bankruptcy examiners, ${ }^{228}$ could also actively participate in large charitable reorganizations and intervene in cases where the examiner reports findings of pre-petition misconduct.

\section{Repeal of charitable exemption from involuntary bankruptcy proceedings}

As explained above, Congress could also repeal the charitable exemption from involuntary proceedings. In the for-profit sector, the right of creditors to file an involuntary proceeding gives creditors leverage to insist on bankruptcy as soon as the debtor encounters financial distress. Bankruptcy reorganization tends to preserve going concern value more effectively when the debtor reorganizes earlier rather than later. By exempting charities from involuntary proceedings, the Bankruptcy Code allows blameworthy incumbent charitable fiduciaries to postpone seeking bankruptcy relief until point when the condition of financial distress has become hopelessly irreversible. Although charities, by and large, do not rely on debt financing for capital purposes, charities do have creditors. For example, in its recent bankruptcy proceeding, the Philadelphia Orchestra reported de minimis financial debt but major liabilities to its pensioners and landlord. ${ }^{229}$ The Bankruptcy Code contains ample protection against creditor abuse of the involuntary proceeding remedy, including a requirement that at least three creditors participate and, if the bankruptcy court dismisses the proceeding, petitioners must reimburse the debtor's costs and attorney fees. ${ }^{230}$

\section{CONCLUSION}

The insolvency of a charity jeopardizes the public interest in charitable assets and implicates special problems of institutional governance for reasons related to the "equity-less" feature of the charitable nonprofit form. Outside of bankruptcy, one of the biggest problems facing the charitable nonprofit sector is the lack of accountability imposed on charitable fiduciaries, which too often enables nonprofit officers and directors to engage in mismanagement and misuse of charitable assets without detection, removal, or penalty. The problem of charitable accountability is even more pernicious when a charity becomes insolvent because marketplace systems and aspects of bankruptcy law that con-

227. See, e.g., In re Hyperion Found., Inc., 08-51288-NPO, 2009 WL 2477392 (Bankr. S.D. Miss. Aug. 11, 2009); In re Sheehan Mem'l Hosp., 301 B.R. 777, 780 (Bankr. W.D.N.Y. 2003).

228. Jonathan Lipson, Understanding Failure: Examiners and the Bankruptcy Reorganization of Large Public Companies, 84 AM. BANKR. L.J. 1, 47 (2010) ("The process for choosing an examiner appears to be left to the office of the United States Trustee.")

229. Schedule of Assets and Liabilities, In re Philadelphia Orchestra Ass'n, Doc. No. 187, Case No. 11-13098 (E.D. Pa. Bank. June 15, 2011).

230. 11 U.S.C. $\S 303$. 
strain corporate governance in the for-profit context do not apply in the charitable nonprofit context. Charitable fiduciaries can exploit three weaknesses in particular.

The first weakness arises from a key difference in the way for-profit companies and charities raise capital to fund their operations. In the for-profit context, marketplace systems impose the greatest constraint on corporate governance because for-profit firms routinely include debt financing as part of their capital structure. To minimize the risk of default, commercial financing agreements commonly impose loan covenants that allow bank lenders to assert control over the borrower's corporate governance at the earliest sign of financial distress long before the point of insolvency. Loan covenants permit banks to monitor the borrower's financial performance and, upon violation of a covenant, accelerate the payment of debt. When a covenant violation occurs, banks typically assert the right to accelerate as leverage to intervene in the borrower's corporate governance and business operation. Perhaps consequently, bank intervention following a covenant violation is strongly correlated with the removal of underperforming corporate managers. In the charitable nonprofit sector, however, debt financing-and, importantly, the external corporate oversight associated with debt financing-is far less prevalent. When charities do use debt to fund their operations, they tend to rely on mortgages and the issuance of tax-exempt bonds, which are credit facilities that rarely (if ever) include covenants. Although large charitable donors sometimes impose covenant-like restrictions, they lack the same incentives as bank lenders to monitor for financial distress and intervene before the point of insolvency. Thus, whereas bank monitoring and intervention provides an effective constraint on corporate governance in the for-profit sector, such arrangements are largely absent in the charitable nonprofit sector.

The second weakness arises from the Bankruptcy Code's failure to account for the "equity-less" feature of the charitable nonprofit form. In for-profit bankruptcy reorganizations, the "absolute priority" rule grants impaired creditors an absolute right to repayment before the debtor's pre-bankruptcy investors can retain ownership in the reorganized entity (unless they provide new value in consideration). This rule tends to reduce incumbency entrenchment and opportunism by giving dissenting creditors a meaningful opportunity to block the confirmation of reorganization plans that preserve incumbent equity interests and, by extension, plans that entrench officers and directors installed by the debtor's incumbent owners. In charitable nonprofit reorganizations, however, there are no incumbent equity interests to extinguish, so the absolute priority rule provides no protection against blameworthy charitable fiduciaries that seek to remain in place after the charity emerges from bankruptcy. Further, in forprofit reorganizations, the absolute priority rule helps constrain incumbents by facilitating a sale of the reorganized debtor to new owners. Indeed, for-profit 
Charitable Insolvency and Corporate Governance in Bankruptcy Reorganization

firms almost invariably undergo a transfer of ownership in bankruptcy reorganization. This is significant because new owners have strong economic incentives to perform due diligence on incumbent officers and directors before retaining them in the reorganized firm, thus increasing the likelihood that blameworthy incumbents will be identified and removed. In charitable nonprofit reorganizations, however, no transfer of ownership occurs because the charitable nonprofit form prohibits proprietary ownership interests. The absence of new ownership increases the likelihood that a charity entering bankruptcy with dysfunctional leadership will emerge from bankruptcy with dysfunctional leadership.

The third weakness relates to the Bankruptcy Code's charitable exemption from involuntary proceedings. As a general rule, bankruptcy relief is most effective at preserving enterprise value when invoked early, before a critical mass of individual creditors assert claims outside of bankruptcy. Piecemeal collection outside of bankruptcy deprives the debtor of assets necessary to operate its business, which, in turn, impairs the debtor's enterprise value as a going concern. Incumbent officers and directors, however, tend to delay seeking bankruptcy relief until the debtor has passed the point of financial rehabilitation. To constrain delay, the Bankruptcy Code allows creditors to bring involuntary proceedings against insolvent, for-profit debtors that refuse to invoke bankruptcy relief voluntarily. Although formal involuntary proceedings are infrequent, the right to bring an involuntary case provides creditors with leverage when dealing with stubborn or incompetent corporate managers. Charities, however, are entirely exempt from involuntary proceedings. ${ }^{231}$ This exemption ostensibly exists to protect charities, but, in practice, the exemption may do more harm than good. Blameworthy charitable incumbents are equally prone to delay as their for-profit counterparts, but creditors lack comparable protection to constrain dilatory behavior. This adversely affects the public interest because delay in seeking bankruptcy relief often imposes large unnecessary costs on the charity itself and threatens prospects for successful reorganization.

Consequently, incumbent charitable fiduciaries responsible for causing a charity's financial distress are unlikely to be removed during bankruptcy reorganization. Failure to remove blameworthy charitable fiduciaries undermines prospects for successful reorganization that, in the long run, harms the public interest in charitable assets. To better protect the public interest, lawmakers might consider reform designating the bankruptcy reorganization as a mandatory point of governmental intervention to investigate insolvent charities and remove blameworthy actors from the reorganized entity. To this end, the Bankruptcy Code could be amended to provide for the presumptive appointment of bankruptcy examiners in all reorganization cases involving large sums of chari-

231. 11 U.S.C. $\S 303(a)$. 
table assets. In cases where the bankruptcy examiner uncovers fiduciary misconduct or breach, the bankruptcy court could deny confirmation of the charity's reorganization plan until the offending individuals agree to resign from office. To prevent incumbent fiduciaries from avoiding bankruptcy court, Congress might also consider repealing the charitable exemption from involuntary bankruptcy proceedings. 